NBSIR 82-2533

\title{
Solar Energy Systems - Standards for Screening Plastic Containment Materials
}

June 1982

Prepared for

U.S. Department of Energy

Office of Solar Heat Technologies

- QC c ctive Heating and Cooling Division

100 Vashington, DC 20585 



\section{Prepared for}

U.S. Department of Energy

Office of Solar Heat Technologies

Active Heating and Cooling Division

Washington, DC 20585

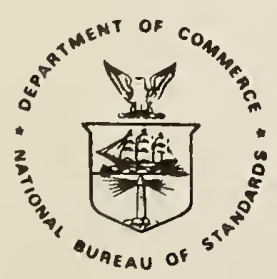

U.S. DEPARTMENT OF COMMERCE, Malcolm Baldrige, Secretary NATIONAL BUREAU OF STANDARDS, Ernest Ambler, Director 



\section{ABSTRACT}

Plastic materials are being chosen more frequently in solar energy systems. Problems with materials in solar systems have indicated a need for standards to assess the performance and durability of the materials. In this investigation, laboratory studies have been performed to obtain data needed to develop standards to screen plastic containment materials for the effects of heat and for compatibility with heat transfer fluids. Five absorbers, three plastic pipe materials, and three plastics used in storage applications have been studied. These materials were evaluated to assess their durability when exposed to heat aging at $100^{\circ} \mathrm{C}$ and $125^{\circ} \mathrm{C}$, and for chemical compatiblity with six heat transfer fluids at room temperature and at $70^{\circ} \mathrm{C}$. After these exposures, the properties measured to evaluate materials durability were hardness, specific gravity, reflectance, and change in dimension.

The results of the laboratory tests are presented and a draft standard for screening plastic containment materials is proposed. 


\section{ACKNOWLEDGMENT}

The authors gratefully acknowledge the contributions of Ms. Anita Sweigert of NBS for assisting with some of the laboratory tests described in this report. In addition, the valuable review comments on draft standards provided by members of ASTM Committee E44 on Solar Energy Conversion are gratefully acknowledged. 


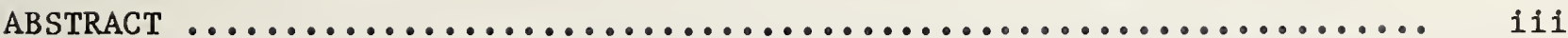

ACKNOWLEDGMENT $\ldots \ldots \ldots \ldots \ldots \ldots \ldots \ldots \ldots \ldots \ldots \ldots \ldots \ldots \ldots \ldots \ldots \ldots \ldots \ldots \ldots \ldots \ldots$ iv

1. INTRODUCTION $\ldots \ldots \ldots \ldots \ldots \ldots \ldots \ldots \ldots \ldots \ldots \ldots \ldots \ldots \ldots \ldots \ldots \ldots \ldots \ldots \ldots \ldots$

1.1 BACKGROUND .....................................

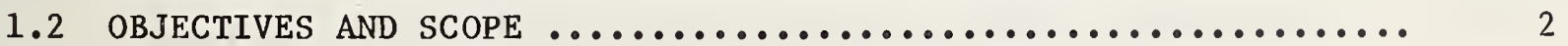

2. PROBLEM ASSESSMENT .................................. 3

2.1 PERFORMANCE REQUIREMENTS $\ldots \ldots \ldots \ldots \ldots \ldots \ldots \ldots \ldots \ldots \ldots \ldots \ldots \ldots \ldots \ldots \ldots \ldots$

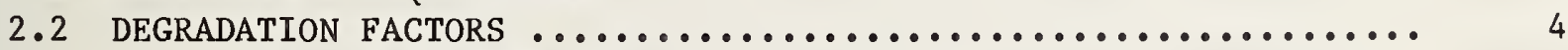

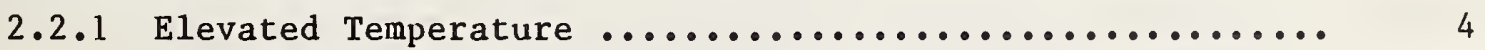

2.2.2 Compatibility with Heat Transfer Fluid .............. 6

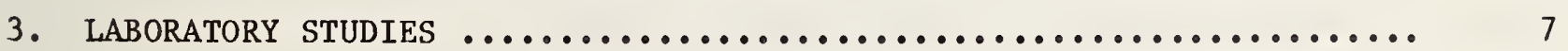

3.1 INTRODUCTION $\ldots \ldots \ldots \ldots \ldots \ldots \ldots \ldots \ldots \ldots \ldots \ldots \ldots \ldots \ldots \ldots \ldots \ldots$

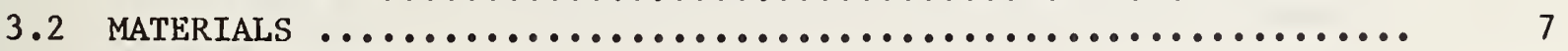

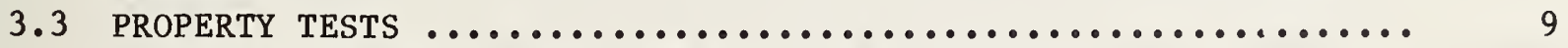

3.4 AGING PROCEDURES TO SIMULATE SERVICE CONDITIONS ............ 10

3.4 .1 Heat Stability Aging ........................ 10

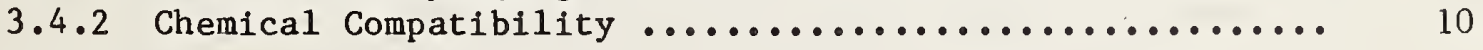

4. RESULTS AND DISCUSSION .............................. 11

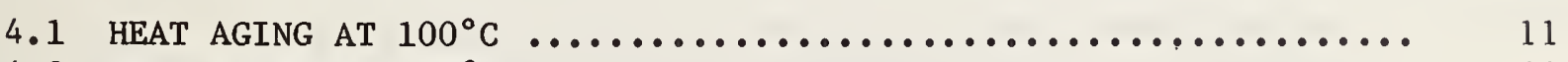

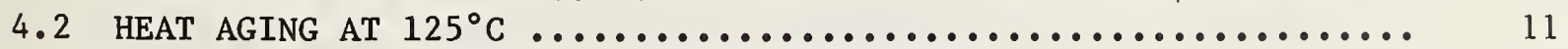

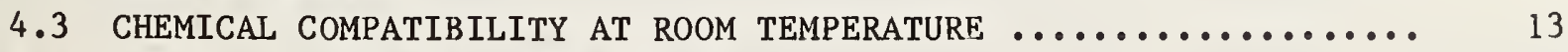

4.4 CHEMICAL COMPATIBILITY AT $70^{\circ} \mathrm{C} \ldots \ldots \ldots \ldots \ldots \ldots \ldots \ldots \ldots \ldots \ldots \ldots \ldots$

5. CONCLUSIONS ....................................... 15

6. PROPOSED STANDARD .................................. 16

6.1 STANDARD PRACTICE FOR SCRLENING CONTAINMENT MATERIALS FOR THE EFFECTS OF HEAT AND HEAT TRANSFER FLUIDS IN SOLAR HEATING AND COOLING SYSTEMS

7. REFERENCES ...................................... 
Table 1. Potential Uses of Plastic Containment Materials in Solar Energy Systems ..................................

Table 2. Service Conditions Potentially Causing Degradation of Plastic Containment Materials ........................ 4

Table 3. Plastic Containment Materials Used in This Study .......... 7

Table 4. Test Methods Used to Measure Material Properties ........... 9

Table 5. Weight Change (Percentage) After Heat Aging at $100^{\circ} \mathrm{C} \ldots . . . . .18$

Table 6. Specific Gravity After Heat Aging at $100^{\circ} \mathrm{C} \ldots \ldots \ldots \ldots$

Table 7. Dimensional Changes (Percentage) After 1000 Hours Heat Aging ...................................... 20

Table 8. Hardness Change After Heat Aging at $100^{\circ} \mathrm{C} \ldots \ldots \ldots \ldots \ldots$

Table 9. Solar Energy Reflectance (Percentage) After Artificial Aging ...................................... 22

Table 10. Weight Change (Percentage) After Heat Aging at $125^{\circ} \mathrm{C} \ldots \ldots . . .23$

Table 11. Specific Gravity After Heat Aging at $125^{\circ} \mathrm{C}$.............. 24

Table 12. Hardness Change After Heat Aging at $125^{\circ} \mathrm{C} \ldots \ldots \ldots \ldots . . \ldots . . . .25$

Table 13. Weight Change (Percentage) After Imnersion at Room Temperature in Heat Transfer Fluids for 7 Days ............. 26

Table 14. Dimension Changes (Percentage) After Immersion at Room Temperature in Heat Transfer Fluids for 7 Days .............

Table 15. Hardness After Imnersion at Room Temperature in Heat

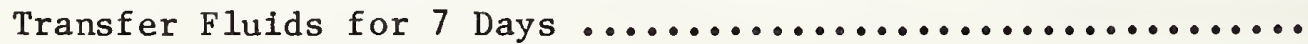

Table 16. Weight Change (Percentage) After Immersion at $70^{\circ}$ in Heat

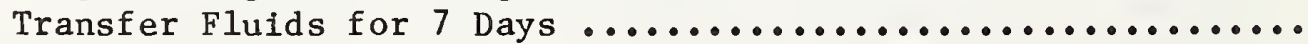

Table 17. Dimensional Changes (Percentage) After Immersion at $70^{\circ} \mathrm{C}$ in Heat Transfer Fluids for 7 Days .......................

Table 18. Hardness After Imnersion at $70^{\circ} \mathrm{C}$ in Heat Transfer Fluids for

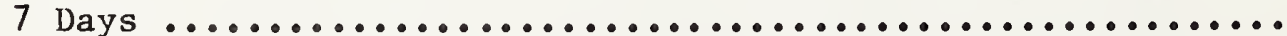

Table Al. Sumnary of Property and Exposure Tests ................. A-7

Table A2. Temperatures for Continuous In-Service Screening .......... A-9 


\section{LIST OF FIGURES}

Page

Figure 1. Shape of Extruded Absorbers ........................ 8

Figure 2. CPVC Pipe After 1000 Hours Heat Aging .................. 12

Figure Al. Testing Sequence $\ldots \ldots \ldots \ldots \ldots \ldots \ldots \ldots \ldots \ldots \ldots \ldots \ldots \ldots \ldots \ldots \ldots \ldots \ldots$ A -11 



\section{INTRODUCTION}

\subsection{BACKGROUND}

As manufacturers of solar energy systems seek to improve their products and lower their costs, innovative materials and designs are being used more often. Frequently, plastics are being chosen to replace more traditional construction materials, particularly in many applications where the material is in contact with the heat transfer fluid. Materials used to contain, transport, or store fluids in solar energy systems are called containment materials. Such applications include absorbers, transport piping systems, and storage facilities. Most commonly, containment materials have been made of metal, i.e., copper, aluminum, or steel. However, recent proposals and manufacturers' literature indicate a trend toward the increased use of plastics. For example, solar collectors for pool heaters are frequently made of plastics, and solar energy systers with plastic containment materials are now available for domestic hot water and space heating applications. This trend is expected to continue as attempts are made to reduce the initial cost of systems, reduce weight, and avoid corrosion.

Plastic materials used in containment applications can be divided into three groups: thermoplastics, thermosets, and elastomers. Thermoplastics soften when pressure and heat are applied and exhibit considerable creep under load, especially at elevated temperatures. The term thermoset is applied to materials which, once heated, react irreversibly so that subsequent applications of heat and pressure do not cause them to soften and flow. Thermosets undergo thermally induced reactions to form densely crosslinked materials. The finished object has a high degree of dimensional stability and is infusible and insoluble. Thermosets normally exhibit higher strength and have less tendency to creep than thermoplastics. However, they are nore brittle than thermoplastics or elastomers. Elastomers or rubbers are linear polymers of high molecular weight which generally have been lightly crosslinked to eliminate flow.

The use of plastics as containment materials introduces a new set of considerations not previously encountered with metals. The mechanical properties of plastics are time and temperature dependent and their long-term durability is less well known than that of the traditional materials (i.e., metals) which they replace. Plastics are readily affected by environmental factors (such as solar radiation, temperature, moisture, air pollutants, and contact with liquids) which can have a wide range of effects on their properties by inducing embrittlement, softening, shrinkage, swelling, creep, and loss of strength and extensibility. Changes in the properties of plastics may occur rapidly or gradual impairment of material properties may occur as a function of time (i.e., stress fatigue).

The consequences of deterioration will vary depending on the particular containment application since the various applications impose different requirements on the plastic containment materials. Plastics acceptable for use in one containment application nay not be acceptable in another. 
As with numerous other materials used in solar energy systems, there is an inadequate data base of materials performance to aid in the selection of plastics for containment materials. An urgent need exists for standards to ensure that plastic materials known to be durable are selected for containment applications. Established test methods and standards for plastics used in conventional construction are usually unsuitable for plastic containment materials for solar energy systems as they do not adequately evaluate durability under the service conditions encountered in solar energy systems. Needed standards must include methods to evaluate performance properties of the plastics and aging tests to assess the ability of the material to resist deterioration caused by environmental exposure tests.

\subsection{OBJECTIVES AND SCOPE}

This study, which was sponsored by the U.S. Departinent of Energy (DoE), had the following objectives:

1) To identify performance requirements for plastic containment materials to be used in active solar systems,

2) To identify and assess existing test methods as candidates for screening tests to evaluate the performance of plastic containment materials,

3) To obtain data needed as the rechnical basis for standards by evaluating commercially available plastic containment materials 1 / according to the performance requirements, and

4) To prepare draft standards for plastic containment materials for consideration by the American Society for Testing and Materials (ASTM).

The scope of the laboratory work described in this report was limited to tests for screening plastic containment materials: 1) for the effects of heat, and 2) for compatibility with heat transfer fluids. The intent was to keep the tests simple so that obviously unsuitable materials could be identified without unduly lengthy and expensive testing. Small coupon test specimens were used.

It is recognized that many other factors, (e.g•, exposure to sunlight, air pollutants, ozone, thermal (ycling, mechanical stresses) may also affect the durability of plastic containment materials. However, screening procedures to assess the effects of these factors are not addressed in this report.

1/ This work does not inclurle rubber hoses which have been previously addressed in "Solar Energy Systems - Standards for Rubber Hose," by Stiehler, R. and Michalak, J。, NBSIR 79-1317, National Bureau of Standards, Washington, DC 20234, 1979. 
2. PROBLEM ASSESSMENT

\subsection{PERFORMANCE REQUIREMENTS}

Potential applications of plastic containment materials in active solar energy systems are listed in table 1. These containment applications are divided into the three broad categories of absorbers, transport piping, and storage facilities. The various containment applications impose different requirements on the plastic materials. The functions of absorbers are to absorb the sunlight and convert it to thermal energy while serving as a conduit for the heat transfer fluid as it extracts thermal energy from the absorber. The function of transport piping is to transport the heat transfer fluid between system components. The purpose of the storage facilities is to hold the heat transfer fluid when it is not circulating through the solar energy system. During the life of the system, materials in all of these containment applications are expected to perform these functions while maintaining their original size and shape. However, the ability of a plastic to retain material properties is dependent upon its ability to resist deterioration resulting from exposure to service conditions of the solar energy system.

Table 1. Potential Uses of Plastic Containment Materials in Solar Energy Systems

\section{Absorbers}

liquid flows through channels liquid flows over the surface air flows through channels air flows over the surface

Transport Piping

piping for transporting liquids hoses for connecting collectors valves pumps air ducts

\section{Storage}

tanks for liquids

liners for tanks

containers for phase change materials

The service conditions which generally affect plastic containment applications are summarized in table 2. As can be seen from the table, the absorbers, piping, and storage tanks should resist deterioration resulting from elevated temperatures, thermal cycling, moisture, air pollutants, and heat transfer 
fluids. In addition, absorbers and other system components unprotected by insulation must be stable to sunlight. All containment materials should be functional at the internal pressures and the loads encountered by the system and at both high operating temperatures and low winter night temperatures. The plastics should not contaminate the heat transfer fluids nor degrade the adjacent materials.

Table 2. Service Conditions Potentially Causing Degradation of Plastic Containment Materials

\begin{tabular}{|c|c|c|c|}
\hline \multirow[b]{2}{*}{ Service Condition } & \multicolumn{3}{|c|}{ Material Application } \\
\hline & Absorbers & $\begin{array}{c}\text { Transport } \\
\text { Piping }\end{array}$ & $\begin{array}{c}\text { Storage } \\
\text { Tanks }\end{array}$ \\
\hline Elevated Temperature & $\checkmark$ & $\sqrt{ }$ & $\sqrt{ }$ \\
\hline Temperature Cycling & $\sqrt{ }$ & $\checkmark$ & $\sqrt{ }$ \\
\hline Solar Radiation & $\checkmark$ & $\begin{array}{l}\text { Only if exposed } \\
\text { directly to sun- } \\
\text { light }\end{array}$ & $\begin{array}{l}\text { Only if exposed } \\
\text { directly to sun- } \\
\text { light }\end{array}$ \\
\hline Moisture & $\checkmark$ & $\sqrt{ }$ & $\checkmark$ \\
\hline Air Pollutants & $\checkmark$ & $\begin{array}{l}\text { Only if exposed } \\
\text { directly to } \\
\text { atmosphere }\end{array}$ & $\begin{array}{l}\text { Only if exposed } \\
\text { directly to } \\
\text { atmosphere }\end{array}$ \\
\hline Internal Pressure & $\checkmark$ & $\checkmark$ & $\checkmark$ \\
\hline Contact with Heat Transfer Fluids & $\checkmark$ & $\checkmark$ & $\sqrt{ }$ \\
\hline Contact with Adjacent Materials & $\checkmark$ & $\sqrt{ }$ & $\checkmark$ \\
\hline
\end{tabular}

\subsection{DEGRADATION FACTORS}

In a properly designed component, durability of a material is related to its ability to resist degradation by its environment. To develop screening procedures for potential containment materials, two service conditions (i.e., elevated temperature and contact with heat transfer fluids) were selected from table 2 for incorporation into initial screening test. Unsuitable performance under either set of conditions is sufficient reason to reject a material for use as in a specific containment application.

\subsubsection{Elevated Temperature}

The temperatures that containment materials reach in solar energy systems vary depending on 1) system operation, 2) specific containment app1ication, 3) system 
design, and 4) weather conditions. A system usually functions either in normal operation mode or in stagnation mode. During normal operation of a system the heat transfer fluid is circulating and continuous in-service temperatures are reached. Stagnation occurs when the sun is shining but the system is not operating to circulate the heat transfer fluid through the collectors to remove heat.

Absorbers, transport piping, and storage tanks are exposed to different temperatures. Higher temperatures cause more serious degradation. Under both stagnation and operation, the absorber experiences temperatures higher than those of either transport piping or storage tanks. The temperature of the transport piping is lower than that of the absorber but higher than that of the storage tanks (unless the storage tank has auxiliary energy input). In general, the temperature of the piping is not elevated during stagnation since the hot fluid is not circulating. An exception to this occurs near the collectors if thermosyphoning occurs. Storage tanks are exposed to lower temperatures than transport piping because the hot fluid is usually diluted by the cooler liquid in the tank. The maximum temperature for the storage tank occurs during operation because during stagnation no heated fluid is added to the tank, thus the storage tank temperature usually declines.

The design and use conditions of the system will establish the exact temperature reached by each component. Due to variations in systems, vastly different temperatures are reached by different solar systems. For example, swimining pool collectors are frequently not glazed and the temperature of the incoming are (pool water) is generally below $32^{\circ} \mathrm{C}\left(90^{\circ} \mathrm{F}\right)$. On the other hand, collectors for space heating systems often have double glazing and the heat transfer fluid may reach $70-80^{\circ} \mathrm{C}\left(\sim 160-180^{\circ} \mathrm{F}\right)$ during operation. Stagnation temperatures are even higher. Clearly, a plastic suitable at temperatures in a swimming pool application may not be suitable at temperatures in a heating system.

Stagnation temperatures (measured and calculated) for various collectors have been reported. Solar collector performance data for six commercial black plastic collectors published by the California Energy Commission [1] and Florida Solar Energy Center [2] indicate that, under weather conditions of $1040 \mathrm{~W} / \mathrm{m}^{2}$ (330 Btu/ft $\mathrm{ft}^{2} \mathrm{hr}$ ) irradiance and $41^{\circ} \mathrm{C}\left(105^{\circ} \mathrm{F}\right)$ ambient temperature, the stagnation temperatures range between $76-88^{\circ} \mathrm{C}\left(168-191^{\circ} \mathrm{F}\right)$ for unglazed collectors and $90-170^{\circ} \mathrm{C}\left(194-338^{\circ} \mathrm{F}\right)$ for glazed collectors.2/ In another study [3], under similar conditions the temperature of single glazed collectors with flat black metal absorbers varied from $134-159^{\circ} \mathrm{C}\left(273-318^{\circ} \mathrm{F}\right)$ while double glazed collectors with flat black metal absorbers ranged from $148-194^{\circ} \mathrm{C}\left(298-381^{\circ} \mathrm{F}\right)$.

Plastic materials exposed to heat may also be subject to many types of physical, mechanical, and chemical changes. The severity of the exposure in both time and temperature determines the extent and type of changes that take place. A plastic material is not necessarily degraded by exposure to elevated temperatures, for example, after short exposures it may be unchanged or improved.

2/ Clear plastic collectors using a dark heat transfer fluid would have lower stagnation temperatures. 
However, extended periods of exposure of plastics to elevated temperatures will generally cause some degradation, with progressive change in physical properties.

Some plastic materials may become brittle due to loss of plasticizer or decrease in molecular weight after exposure at elevated temperatures. Other types of plastics become soft and sticky, either due to sorption of volatilized plasticizer or due to breakdown of the polymer.

\subsubsection{Compatibility with Heat Transfer Fluid}

The heat transfer fluids most commonly used in solar systems are water, ethylene glycol, propylene glycol, and silicone oil. (The glycols are generally diluted with water to a 50 percent solution.) Potential compatibility problems arise from penetration of the fluid into the plastic, extraction of stabilizers or plasticizers from the plastic, or erosion of the interior walls of the plastic caused by fluid flow. The plastic may swell, soften, or lose strength properties. 


\section{LABORATORY STUDIES}

\subsection{INTRODUCTION}

The laboratory studies consisted of measurement of selected properties of typical containment materials, exposure of materials to aging procedures which simulate service conditions in solar systems, and subsequent remeasurement of properties. This report addresses the measurement of hardness, dimensions, weight, and reflectance, and evaluates the effects of heat and heat transfer fluids on these properties.

\subsection{MATERIALS}

The containment materials used in this study were typical of those commercially available. Six materials were from collector absorbers, three were piping materials, two were tank liners and one was a tank material. The materials are listed in table 3. All of the absorbers plus the ABS pipe and the

Table 3. Plastic Containment Materials Used in This Study

\begin{tabular}{|c|c|}
\hline Materials & Description \\
\hline Collectors - Absorbers & \\
\hline Ethylene propylene diene monomer (EPDM) & extrusion with $1.9 \mathrm{~mm}$ wall \\
\hline Silicone coated fiberglass fabric & $0.36 \mathrm{~mm}$ sheet \\
\hline Crosslinked polyethylene (XLPE) & $\begin{array}{l}17 \mathrm{~mm} \text { diameter tubing with } \\
1.5 \mathrm{~mm} \text { wall }\end{array}$ \\
\hline Polypropylene & extrusion, with $0.5 \mathrm{~mm}$ wall \\
\hline $\begin{array}{l}\text { Polypropylene copolymer } \\
\text { Piping }\end{array}$ & extrusion, with $0.64 \mathrm{~mm}$ wall \\
\hline Chlorinated poly(vinyl chloride) (CPVC) & $34 \mathrm{~mm} \mathrm{OD,} 4.5 \mathrm{~mm}$ wall \\
\hline Poly(vinyl chloride) (PVC) & $34 \mathrm{~mm} \mathrm{OD,} 4.5 \mathrm{~mm}$ wall \\
\hline $\begin{array}{l}\text { Acrylonitrile-butadiene-styrene (ABS) } \\
\text { Storage }\end{array}$ & $29 \mathrm{~mm} \mathrm{OD,} 2.2 \mathrm{rmm}$ wall \\
\hline Poly(viny1 chloride) liner & $0.8 \mathrm{~mm}$ sheet \\
\hline $\begin{array}{l}\text { Chlorosulfonated polyethylene liner - over } \\
\text { woven fabric }\end{array}$ & $0.8 \mathrm{~mm}$ sheet \\
\hline Fiber reinforced plastic tank & $1.3 \mathrm{~mm}$ sheet \\
\hline
\end{tabular}


chlorosulfonated polyethylene liner were black, due to the addition of carbon black to the plastic during processing. The PVC and CPVC pipe were different shades of gray, while the PVC liner was blue, and the fiber reinforced tank material was transparent.

The shape of the absorbers occasionally interfered with measurement of certain properties. Figure 1 illustrates their shapes.

ETHYLENE PROPYLENE DIENE MONOMER

CROSSLINKED POLYETHYLENE

POLYPROPYLENE

\section{POLYPROPYLENE COPOLYMER}

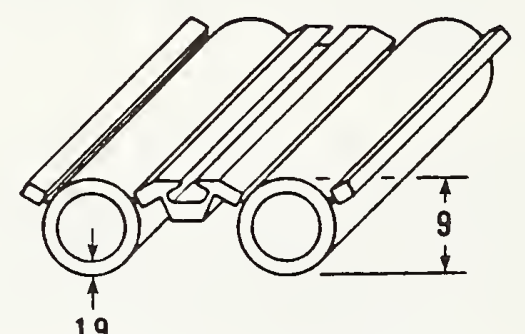

1.9
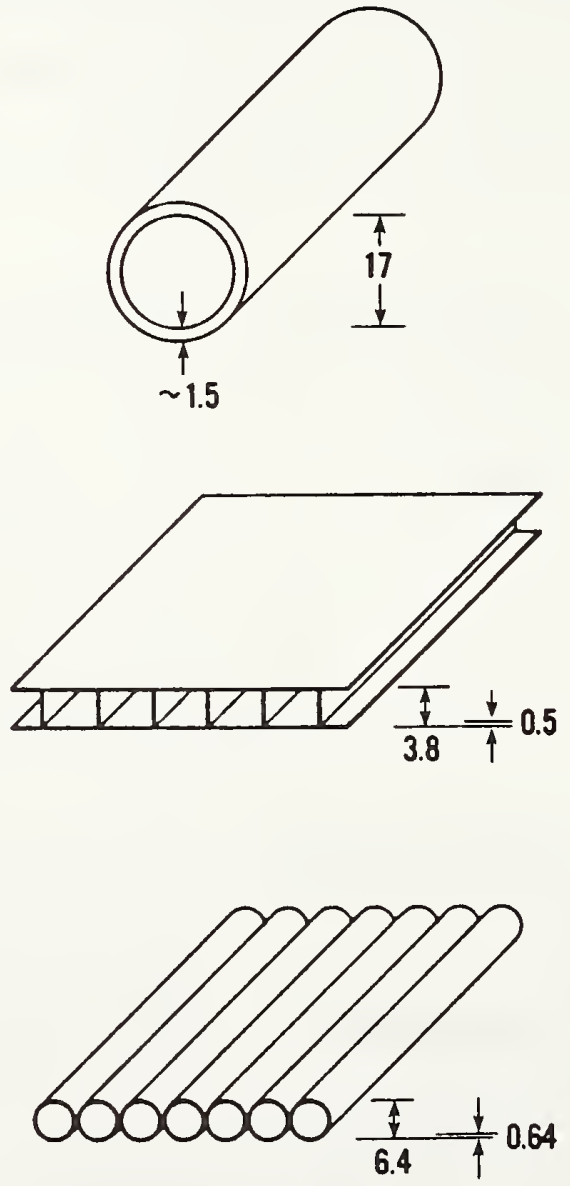

All dimensions in $\mathrm{mm}$. 


\subsection{PROPERTY TESTS}

The property tests which were performed are listed in table 4.

Table 4. Test Methods Used to Measure Material Properties

\begin{tabular}{|c|c|}
\hline Property & ASTM Method \\
\hline Appearance & Visual observations \\
\hline Dimensions & D471 - Method for Rubber Property - Effect of Liquids [4] \\
\hline Hardness & $\begin{array}{r}\text { D785 - Method for Rockwel1 Hardness of Plastics and } \\
\text { Electrical Insulating Materials [5] }\end{array}$ \\
\hline & $\begin{array}{l}\text { D2240 - Method for Rubber Property - Durometer } \\
\text { Hardness [6] }\end{array}$ \\
\hline Reflect ance & $\begin{aligned} \text { E424 - } & \text { Methods for Solar Energy Transmittance and } \\
& \text { Reflectance (Terrestrial) of Sheet Materials [7] }\end{aligned}$ \\
\hline $\begin{array}{l}\text { Specific Gravity } \\
\text { and Weight }\end{array}$ & $\begin{array}{l}\text { D792 - Methods for Specific Gravity and Density of } \\
\text { Plastics by Displacement [8] }\end{array}$ \\
\hline
\end{tabular}

The appearance of the test specimens was checked by visual observation after heat stability and chemical compatibility exposures were completed. Obvious changes in color, size or shape were noted.

Dimensional changes were determined according to the procedures in ASTM D 471 , Method for Rubber Property Effect of Liquids [4]. For the piping and tubular samples, the wall thickness was measured, while for the other samples the length and width were measured.

Hardness was evaluated using ASTM D785, Method for Rockwel1 Hardness of Plastics and Electrical Insulating Materials [5], and D2240, Method for Rubber Property - Durometer Hardness [6]. Hardness is the resistance of a material to indentation. Hardness measurement of plastics and rubber takes the form of forcing a standard indentor under a known load into a flat surface of the materials and measuring the resulting degree of penetration. Method D785 makes use of the Rockwell hardness tester. It has five scales which overlap to a degree. Method D 2240 uses the Shore durometer and has two scales. Type A Shore hardness is for soft materials and Type D is for hard materials. Since indentation is a complex function of properties including modulus, force, and indentor profile, hardness values measured using one method cannot generally be compared with those derived from another.

Solar energy reflectance is an important factor in the capture of solar energy by a solar collector absorber. Any energy which is reflected cannot be absorbed to heat the collector. Spectral reflectance was measured over the solar energy 
range from 300 to $2150 \mathrm{~nm}$ using ASTM E424, Methods for Solar Energy Transmittance and Reflectance (Terrestrial) of Sheet Materials [7]. Solar reflectance was calculated using air mass 2 .

The specific gravity and weight of the test specimens were measured using ASTM D792, Methods for Specific Gravity and Density of Plastics by Displacement [8]. Specific gravity is the ratio of the weight of a material in air to the weight of an equal volume of distilled water in air. Specific gravity can be used to follow physical changes in a sample, to indicate degree of uniformity among different test specimens, and to indicate average density of a large item. Changes in density of a specimen may be due to changes in crystallinity, loss of plasticizer, absorption of solvent or to other causes. Parts of a sample may differ in density because of difference in crystallinity, porosity, and composition (proportion of resin, plasticizer, pigment or filler).

\subsection{AGING PROCEDURES TO SIMULATE SERVICE CONDITIONS}

\subsubsection{Heat Stability Aging}

Temperatures of $100^{\circ} \mathrm{C}\left(212^{\circ} \mathrm{F}\right)$ and $125^{\circ} \mathrm{C}\left(257^{\circ} \mathrm{F}\right)$ were selected for the heat aging. Separate sets of test specimens were used for each temperature. Each set consisted of three test specinens, approximately four inches square. The specimens were placed in a horizontal, completely supported position in a mechanical convection oven during the heat aging. The materials were evaluated for linear dimensions, hardness, weight change, appearance, and reflectance (absorbers only) after $100,250,500$, and 1,000 hours exposure.

\subsubsection{Chemical Compatibility}

Compatibility of the materials with the heat transfer fluids was evaluated using the procedure described in ASTM D543, Test for Resistance of Plastics to Chemical Reagents [9]. The test specimens were immersed in the heat transfer fluids. Each test specimen was placed in a wide mouth glass jar containing about $400 \mathrm{ml}$ of heat transfer fluid. When necessary, weights were attached to assure that the test specinen was immersed. The heat transfer fluids were: water; 100 percent ethylene glycol; 50 percent ethylene glycol in water; 100 percent propylene glycol; 50 percent propylene glycol in water; 100 percent silicone oil. Tops with inert liners were placed on all jars. One set of test specimens was exposed at room temperature, while a second set was placed in an oven at $70^{\circ} \mathrm{C}\left(158^{\circ} \mathrm{F}\right)$. After one week as specified in ASTM D543 the materials were evaluated for linear dimensions, hardness, weight change, appearance and reflectance (absorbers only). 


\section{RESULTS AND DISCUSSION}

The primary purpose of the research described in this report was to obtain laboratory data needed to develop the technical basis for standards to screen plastic containment materials, and not to evaluate commercially available plastic containment materials. However, in order to develop the needed data, it was essential that a variety of plastic containment materials be tested. No attempt was made to test every type of plastic containment material on the market. The materials selected were typical of those commercially available. Many plastic containment materials are marketed and, in order to improve their performance, manufacturers sometimes modify the materials. The properties of a material can be changed by alterations in minor constituents (i.e. stabilizers, plasticizers, antioxidants), in processing techniques, and in chemical composition. The properties of materials currently on the market may differ from those described in this report. The reader is cautioned against direct application of these data to materials currently on the market.

\subsection{HEAT AGING AT $100^{\circ} \mathrm{C}$}

The weight changes resulting from the $100^{\circ} \mathrm{C}$ exposures are shown in table 5 . The greatest weight loss ( 8.0 percent) occurred with the storage PVC tank liner. The EPDM lost 2.5 percent weight and the chlorosulfonated polyethylene liner lost 1.5 percent weight. At first, the ABS pipe lost weight, but then regained it. The initial loss is probably due to plasticizer loss while the gain could be accounted for by oxidation. The other materials lost less than one percent. The specific gravity values after heat aging at $100^{\circ} \mathrm{C}$ are given in table 6 . In general, the changes are sma11, although PVC tank liner increased 2.4 percent after 1,000 hours.

Dimensional changes are given in tahle 7. The anisotropic nature of the materials is illustrated by the unequal changes in the length and width and wall thickness. The extruded shapes of most of the materials made it difficult to accurately measure dimensional changes. Consequently, the values reported are approximate. Hardness data are reported in table 8 . In general the hardness increased slightly, although it rose significantly for the PVC tank liner. Reflectance values are given in table 9. The changes in reflectance after 1,000 hours were minimal with the largest occurring with FPIJM which went from 4.5 percent to 3.6 percent.

\subsection{HEAT AGING AT $125^{\circ} \mathrm{C}$}

Only absorber and piping materials were exposed to heat aging at $125^{\circ} \mathrm{C}$. Weight changes after this exposure are given in table 10. Three materials (EPDM, CPVC pipe, and PVC pipe) had significant weight losses after 1,000 hours. The EPDM had a gradual weight loss over time, whereas the CPVC and PVC pipe had significant losses between 500 and 1,000 hours. During this time, the CPVC pipe developed bubble-looking bumps on the interior and exterior surfaces, as shown in figure 2 . 

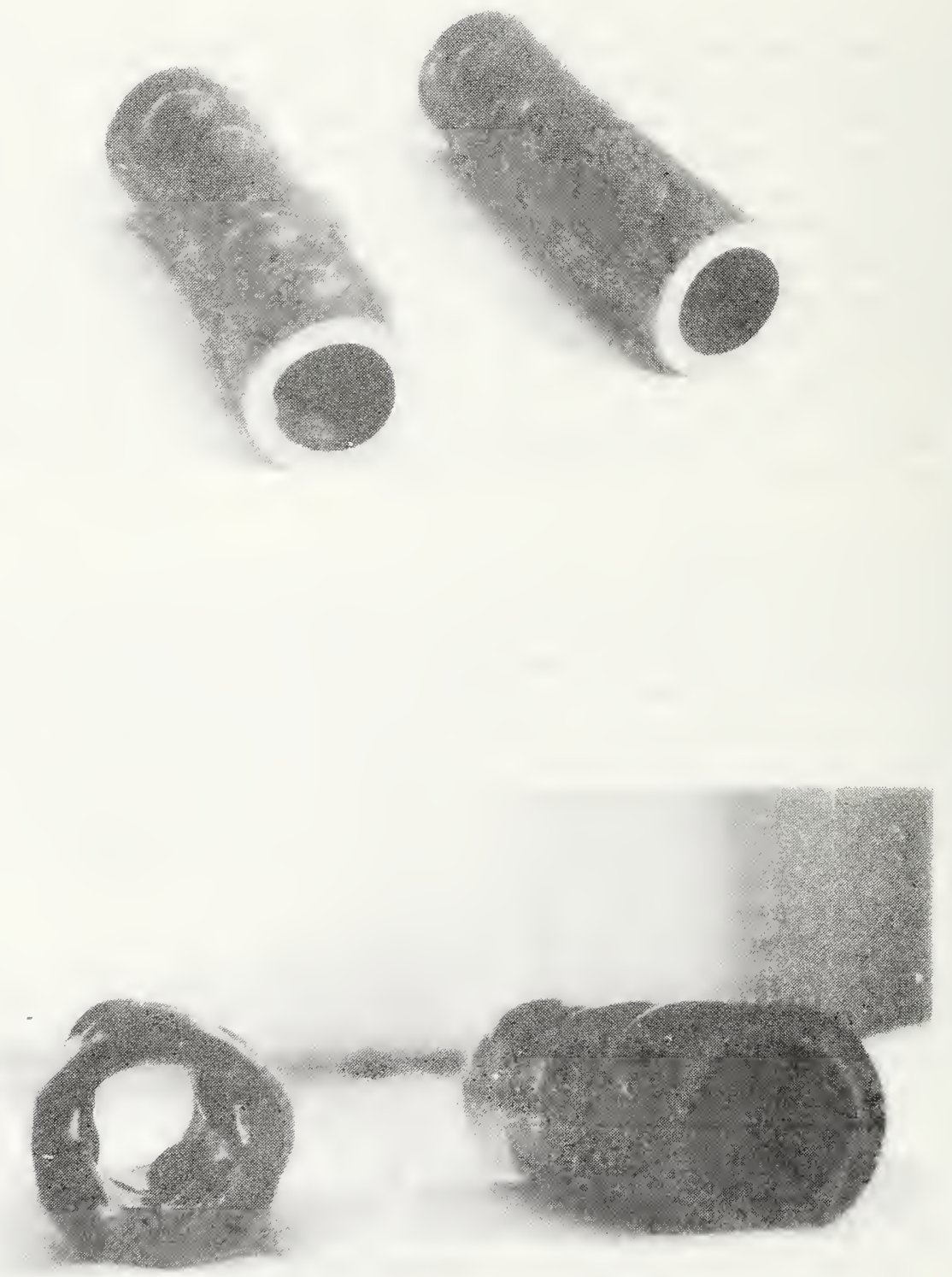

Figure 2. CPVC Pipe After 1000 Hours Heat Aging 
The specific gravities of the exposed materials are shown in table 11. The greatest change (loss) occurred with the CPVC pipe. The silicone coated fiberglass fabric had smaller losses. The EPDM and the ABS pipe showed gradual increases amounting to 2.6 and 1.5 percent, respectively.

Dimensional changes are given in table 7. The crosslinked polyethylene absorber softened and deformed to the extent that meaningful measurements could not be made. The ABS pipe softened during the heat aging and it adopted an oval shape. The ABS pipe shortened about 17 percent and the ends flared making it impossible to measure wall thickness. Bubbles in the CPVC pipe also prevented meaningful measurement of wall thickness. Hardness changes are given in table 12 .

\subsection{CHEMICAL COMPATIBILITY AT ROOM TEMPERATURE}

The weight changes resulting from the immersion in heat transfer fluids at room temperature are shown in table 13. In general, the changes are small. Silicone oil had the greatest effect on the materials, generally causing them to swell, (e.g., ABS pipe gained 21.5 percent and the chlorosulfonated polyethylene liner gained 34 percent). In comparing the materials immersed in the concentrated ethylene and propylene glycols with the corresponding solutions diluted 50 percent with water, it appears that the only significant differences were for the polypropylene absorber and the PVC liner. The polypropylene absorber gained about 0.1 percent weight in the concentrated propylene glycol but lost 23 percent in the dilute solution while the PVC liner lost 3.5 percent weight in the concentrated propylene glycol but only 0.2 percent in the 50:50 solution.

Dimensional changes after immersion in the heat transfer fluid are given in table 14. Changes less than one percent are not listed in the table. In general, silicone oil again had the largest effect on the materials although the ABS pipe swelled 10 percent in the propylene glycol/water solution.

Hardness after iramersion in the room temperature fluids is shown in table 15. The EPDM became slightly harder in all fluids except the ethylene glycol. The PVC pipe softened somewhat in all fluids. The ABS pipe and chlorosulfonated polyethylene liner softened in silicone oil.

Reflectance of the materials after immersion is shown in table 9. The EPDM decreased from 4.5 percent to 3.6 percent after the distilled water imnersion, with smaller losses caused by the other fluids. The silicone coated fiberglass fabric changed very little. The propylene absorber remained essentially unchanged except in the silicone oil, which caused the reflectance to decline from 4.4 percent to 3.3 percent. The reflectance of the propylene copolymer absorber decreased from 3.5 percent to 2.2 percent and 2.1 percent from the ethylene glycol and propylene glycol/water solutions, respectively. The reflectance of the chlorosulfonated polyethylene liner was most affected by the concentrated ethylene and propylene glycols. 


\subsection{CHEMICAL COMPATIBILITY AT $70^{\circ} \mathrm{C}$}

The weight changes caused by immersion in the heat transfer fluids at $70^{\circ} \mathrm{C}$ are shown in table 16. Silicone oil caused significant weight gains in all materials which were exposed at this temperature. The crosslinked polyethylene absorber, CPVC pipe, and PVC pipe were essentially unchanged by the other fluids and only the distilled water caused much other change in the ABS.

Dimensional changes measured after immersion in the hot fluids are shown in table 17. They indicate that silicone oil causes the greatest changes. Small changes of less than one percent are not shown.

Hardness values measured after immersion in the heat transfer fluids at $70^{\circ} \mathrm{C}$ are given in table 18. Silicone oil generally caused the materials to soften appreciably while other hot fluids had much less effect. 


\section{CONCLUSIONS}

1. The data obtained in this study show that the environment experienced by materials in solar energy systems, (i.e., elevated temperature and contact with heat transfer fluids) can degrade some plastic materials typically used as absorber, piping, and storage materials.

2. Accelerated laboratory screening tests can be used as an effective means of determining if plastic materials are likely to be affected by specific degradation factors, such as elevated temperature or contact with heat transfer fluids. Thus, these test methods can provide a basis for evaluation standards which aid in screening materials.

3. Exposure to elevated temperature is an important test in evaluating plastic materials for application in active solar systems. Many polymeric materials are susceptible to thermal degradation in the range of in-service temperatures of solar systems. Oven aging at $100^{\circ} \mathrm{C}$ and $125^{\circ} \mathrm{C}$ showed that some candidate plastic materials are dimensionally unstable, lose weight, become harder, or change reflectance.

4. Exposure to heat transfer fluids is also an important test in evaluating the chemical compatibility of the plastic and the fluid. Exposure of the plastics to six heat transfer fluids at both room temperature and $70^{\circ} \mathrm{C}$ illustrated that there are interactions between the plastic and fluid. Silicone oil generally caused the plastics to swell, soften, and gain weight. The effects of the other fluids ranged from essentially no change to increases in hardness or softness, weight gains, or dimensional changes.

5. The procedures described in this report are intended to provide data to screen out unsuitable materials and to provide a basis for establishing an initial relative ranking of the resistance of candidate materials to heat and to heat transfer fluids. Components in solar heating and cooling systems experience different levels of environmental exposure and mechanical stresses. Additional exposure and property measurement tests are recommended to evaluate candidate materials, especially when such tests more closely simulate field service conditions and when candidate materials are fabricated as components of actual solar systems. 


\section{PROPOSED STANDARD}

Based upon the laboratory work reported in this report, a standard for use in evaluation of plastic containment materials in solar heating and cooling systems was drafted and submitted for consideration for acceptance as a consensus standard by ASTM Committee E44 on Solar Energy Conversion, Subcommittee E44.04 on Materials Performance. The proposed standard is included as Appendix $A$ of this report.

6.1 STANDARD PRACTICE FOR SCREENING POLYMERIC CONTAINMENT MATERIALS FOR THE EFFECTS OF HEAT AND HEAT TRANSFER FLUIDS IN SOLAR HEATING AND COOLING SYSTEMS

This is a proposed practice for screening polymeric materials for containment applications in solar heating and cooling systems by determining the effects of heat and heat transfer fluids on selected properties. It provides both exposure procedures and property measurement tests. The exposure procedures are relatively short-term exposures intended to screen out unsuitable materials. Procedures are included for exposure to heat representative of potential application temperatures and to heat transfer fluids. The property measurement tests included are appearance, dimensions, hardness, mass, flexural and tensile properties. 


\section{REFERENCES}

[1] Testing Results from Testing and Inspection Program for Solar Equipment, P500-80-056, California Energy Commission, October 1980 .

[2] Summary Information Sheets, FSEC 非8093D, 非9014D, \#80041D, 非80118W, \#80145D, dated Apri1 1979 through January 1981. Available from Florida Solar Energy Center, 300 State Road, Cape Canaveral, FL 32920.

[3] Clark, E. J., Roberts, W. E., Grimes, J. W., and Embree, E. J., "Solar Energy Systems - Standards for Cover Plates for Flat Plate Solar Collectors", National Bureau of Standards Technical Note 1132 (1980). Available from U. S. Superintendent of Documents, U. S. Government Printing Office, Washington, DC 20402.

[4] ASTM D471, Standard Test Method for Rubber Property - Effect of Liquids, Annua1 Book of ASTM Standards, Part 37, American Society for Testing and Materials, 1916 Race Street, Philadelphia, PA 19103.

[5] ASTM D785, Standard Test Method for Rockwell Hardness of Plastics and Electrical Insulating Materials, Annual Book of ASTM Standards, Part 35, American Society for Testing and Materials, 1916 Race Street, Philadelphia, PA 19103.

[6] ASTM D2240, Standard Test Method for Rubber Property - Durometer Hardness, Annual Book of Standards, Part 35, American Society for Testing and Materials, 1916 Race Street, Philadelphia, PA 19103.

[7] ASTM E424, Standard Test Methods for Solar Energy Transmittance and Reflectance (Terrestrial) of Sheet Materials, Annual Book of Standards, Part 46, American Society for Testing and Materials, 1916 Race Street, Philadelphia, PA 19103.

[8] ASTM D792, Standard Test Methods for Specific Gravity and Density of Plastics by Displacement, Annual Book of Standards, Part 35, American Society for Testing and Materials, 1916 Race Street, Philadelphia, PA 19103.

[9] ASTM D543, Standard "'est for Resistance of Plastics to Chemical Reagents, Annual Book of Standards, Part 35, American Society for Testing and Materials, 1916 Race Street, Philadelphia, PA 19103. 
Table 5. Welght Change (Percentage) After Heat Aging At $100^{\circ} \mathrm{C}$

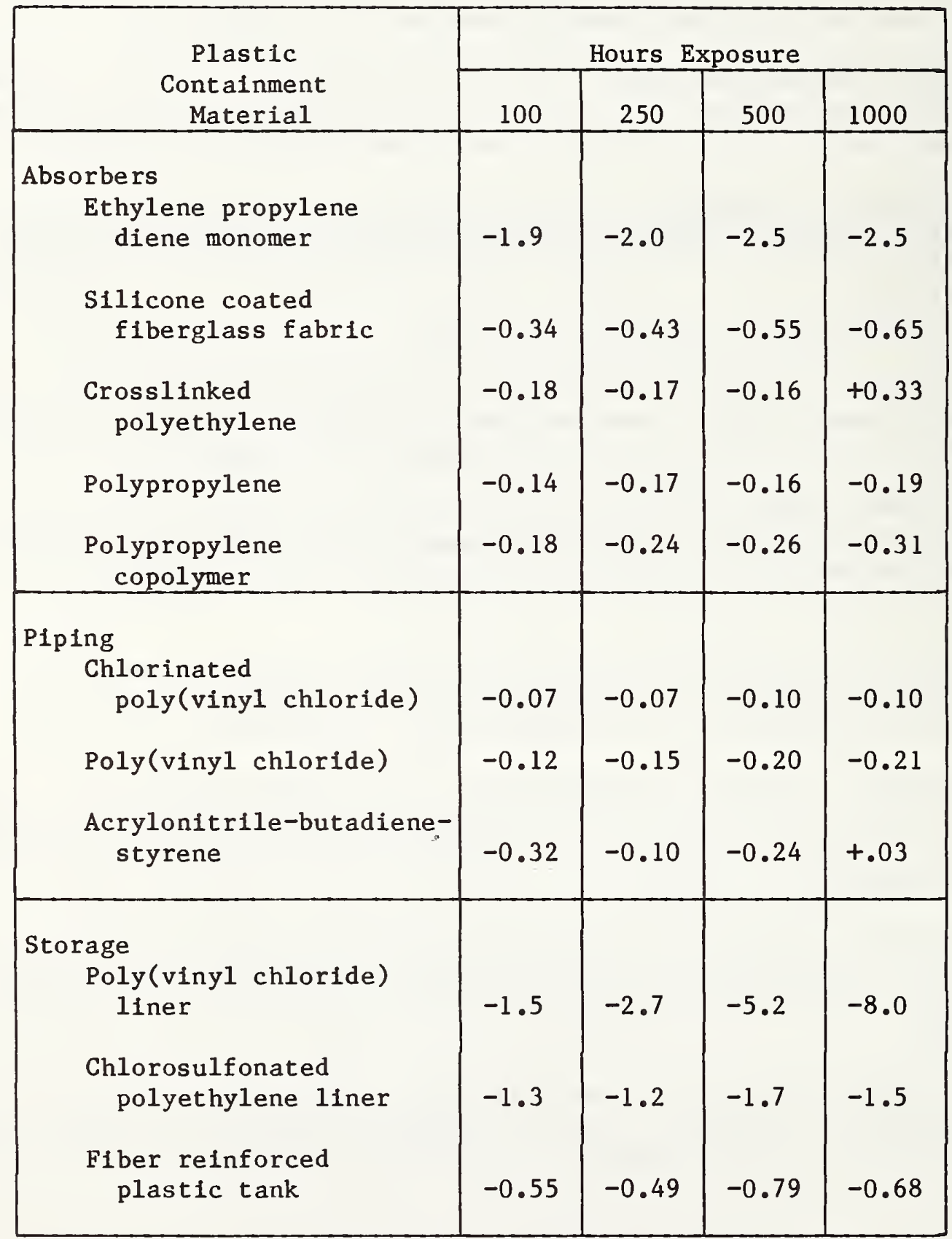

NOTE: These values are the average of three test specimens. 
Table 6. Specific Gravity After Heat Aging At $100^{\circ} \mathrm{C}$

\begin{tabular}{|c|c|c|c|c|c|}
\hline \multirow{2}{*}{$\begin{array}{c}\text { Plastic } \\
\text { Containment } \\
\text { Material } \\
\end{array}$} & \multirow{2}{*}{$\begin{array}{l}\text { Initial } \\
\text { Specific } \\
\text { Gravity }\end{array}$} & \multicolumn{4}{|c|}{ Hours Exposure } \\
\hline & & 100 & 250 & 500 & 1000 \\
\hline $\begin{array}{l}\text { Absorbers } \\
\text { Ethylene propylene } \\
\text { diene monomer }\end{array}$ & 1.167 & 1.160 & 1.165 & 1.164 & 1.169 \\
\hline $\begin{array}{l}\text { Silicone coated } \\
\text { fiberglass fabric }\end{array}$ & $\begin{array}{l}1.508 \\
1.511 \\
1.512\end{array}$ & $\begin{array}{l}1.524 \\
1.510 \\
1.513\end{array}$ & $\begin{array}{l}1.507 \\
1.495 \\
1.499\end{array}$ & $\begin{array}{l}1.502 \\
1.493 \\
1.499\end{array}$ & $\begin{array}{l}1.488 \\
1.502 \\
1.492\end{array}$ \\
\hline $\begin{array}{l}\text { Crosslinked } \\
\text { polyethylene }\end{array}$ & 0.930 & 0.933 & 0.933 & 0.934 & 0.941 \\
\hline Polypropylene & 0.909 & 0.910 & 0.912 & 0.912 & 0.912 \\
\hline $\begin{array}{c}\text { Polypropylene } \\
\text { copolymer }\end{array}$ & 0.917 & 0.917 & 0.918 & 0.917 & 0.918 \\
\hline $\begin{array}{l}\text { Piping } \\
\text { Chlorinated } \\
\text { poly(vinyl chloride) }\end{array}$ & 1.574 & 1.573 & 1.574 & 1.573 & 1.574 \\
\hline Poly(vinyl chloride) & 1.387 & 1.390 & 1.391 & 1.391 & 1.391 \\
\hline $\begin{array}{l}\text { Acrylonitrile-butadiene } \\
\text { styrene }\end{array}$ & 1.031 & 1.029 & 1.031 & 1.031 & 1.034 \\
\hline $\begin{array}{l}\text { Storage } \\
\text { Poly(vinyl chloride) } \\
\text { liner }\end{array}$ & 1.240 & 1.243 & 1.250 & 1.254 & 1.270 \\
\hline $\begin{array}{l}\text { Chlorosulfonated } \\
\text { polyethylene liner }\end{array}$ & 1.305 & 1.301 & 1.309 & 1.309 & 1.311 \\
\hline $\begin{array}{l}\text { Fiber reinforced } \\
\text { plastic tank }\end{array}$ & $\begin{array}{l}1.315 \\
1.313 \\
1.311 \\
\end{array}$ & $\begin{array}{l}1.310 \\
1.307 \\
1.309\end{array}$ & $\begin{array}{l}1.312 \\
1.308 \\
1.309 \\
\end{array}$ & $\begin{array}{l}1.310 \\
1.308 \\
1.308 \\
\end{array}$ & $\begin{array}{l}1.312 \\
1.309 \\
1.310 \\
\end{array}$ \\
\hline
\end{tabular}

NOTE: These values are the average of three test specimens for all materials except the silicone coated fiberglass fabric and the fiber reinforced plastic tank. 
Table 7. Dimensional Changes (Percentage) After 1000 Hours Heat Aging

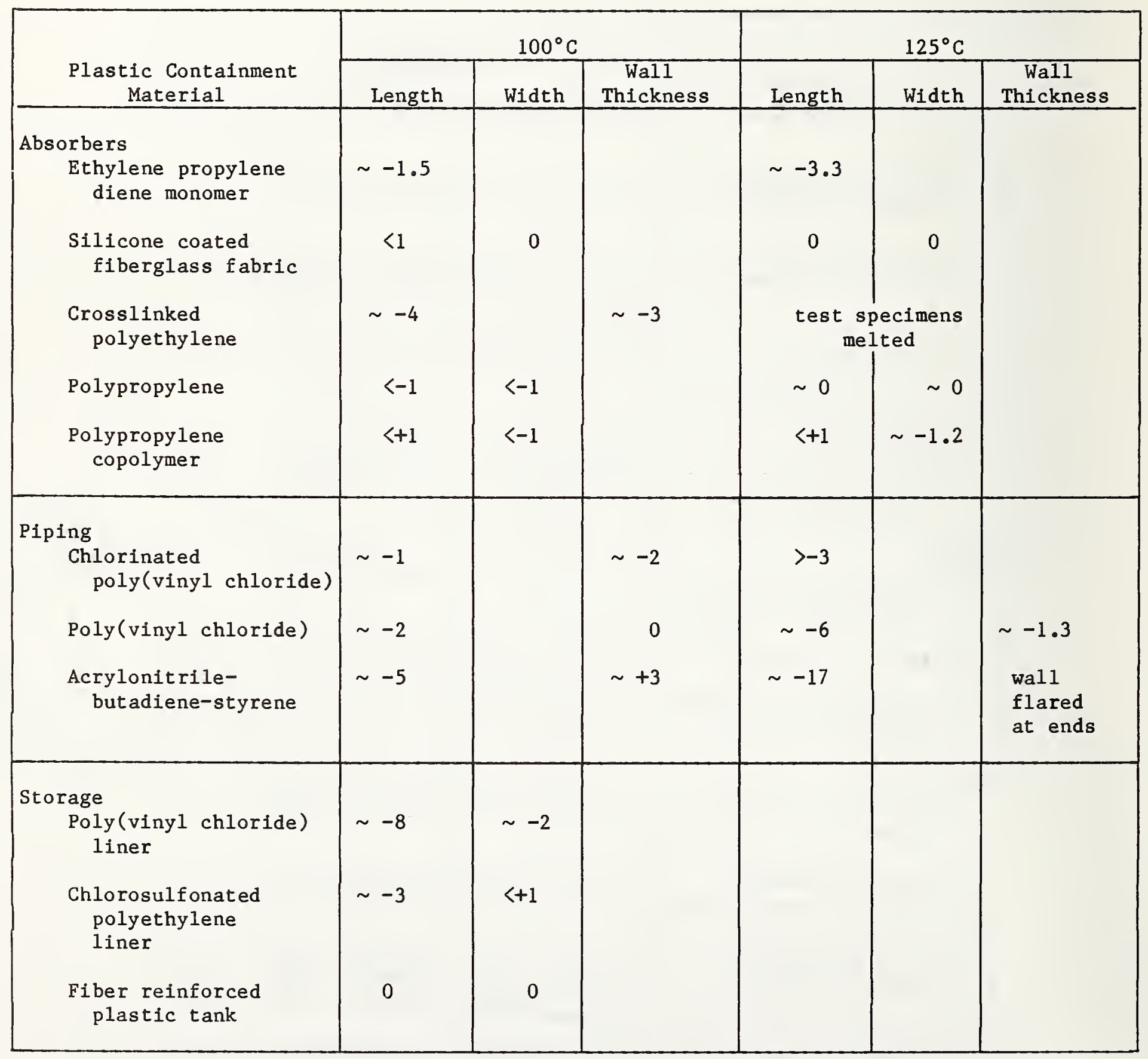

Note: These values are the average of three test specimens. 
Table 8. Hardness Change After Heat Aging at $100^{\circ} \mathrm{C}$

\begin{tabular}{|c|c|c|c|c|c|}
\hline \multirow{2}{*}{$\begin{array}{c}\text { Plastic } \\
\text { Containment } \\
\text { Material }\end{array}$} & \multirow{2}{*}{$\begin{array}{r}\text { Initial } \\
\text { Hardness } \\
\end{array}$} & \multicolumn{4}{|c|}{ Hours Exposed } \\
\hline & & 100 & 250 & 500 & 1000 \\
\hline $\begin{array}{l}\text { Absorbers } \\
\text { Ethylene propylene } \\
\text { diene monomer }\end{array}$ & 26 & 0 & +1 & +3 & +6 \\
\hline $\begin{array}{l}\text { Silicone coated } \\
\text { fiberglass fabric }\end{array}$ & 31 & +2 & +2 & +2 & +4 \\
\hline $\begin{array}{l}\text { Crosslinked } \\
\text { polyethylene }\end{array}$ & 50 & +2 & +2 & +4 & +7 \\
\hline Polypropylene & 57 & +5 & +3 & +4 & +3 \\
\hline $\begin{array}{c}\text { Polypropylene } \\
\text { copolymer }\end{array}$ & 58 & +1 & +3 & +4 & +5 \\
\hline $\begin{array}{l}\text { Piping } \\
\text { Chlorinated } \\
\text { poly (vinyl chloride) }\end{array}$ & 84 & 0 & +2 & +4 & +3 \\
\hline Poly(vinyl chloride) & 82 & +1 & +1 & +3 & +2 \\
\hline $\begin{array}{l}\text { Acrylonitrile-butadiene- } \\
\text { styrene }\end{array}$ & 76 & +2 & +2 & 0 & +7 \\
\hline $\begin{array}{l}\text { Storage } \\
\text { Poly(vinyl chloride) } \\
\text { liner }\end{array}$ & 40 & +2 & +5 & +8 & +12 \\
\hline $\begin{array}{l}\text { Chlorosulfonated } \\
\text { polyethylene liner }\end{array}$ & 42 & +3 & +1 & +3 & +4 \\
\hline $\begin{array}{l}\text { Fiber reinforced } \\
\text { plastic tank }\end{array}$ & 87 & +3 & +1 & +2 & +3 \\
\hline
\end{tabular}

Hardness measured with D2240 Shore Durometer Type D2. A reading of \pm 3 graduations is significant. Reproducibility is \pm 2 graduations. 


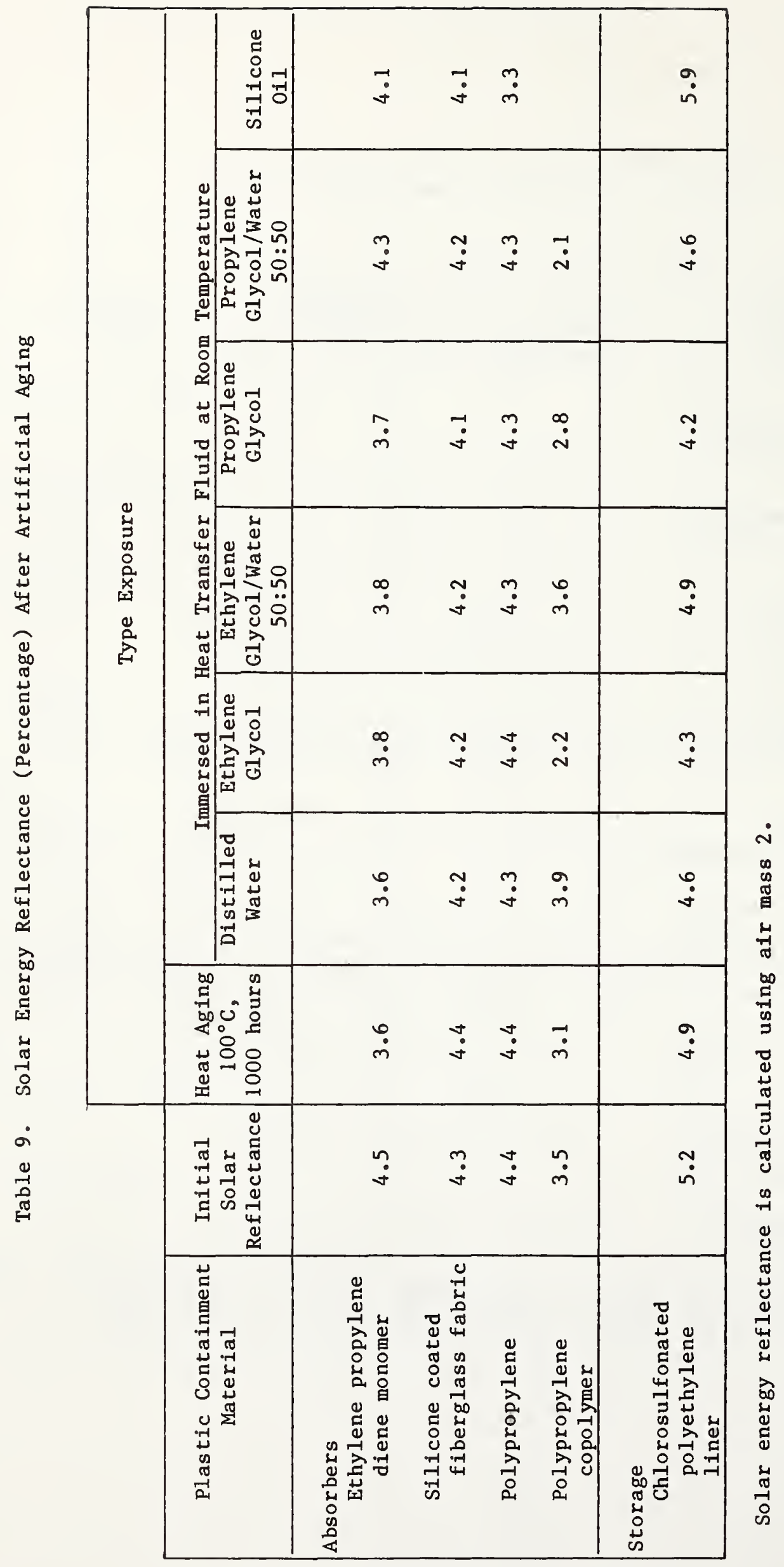


Table 10. Weight Change (Percentage) After Heat Aging at $125^{\circ} \mathrm{C}$

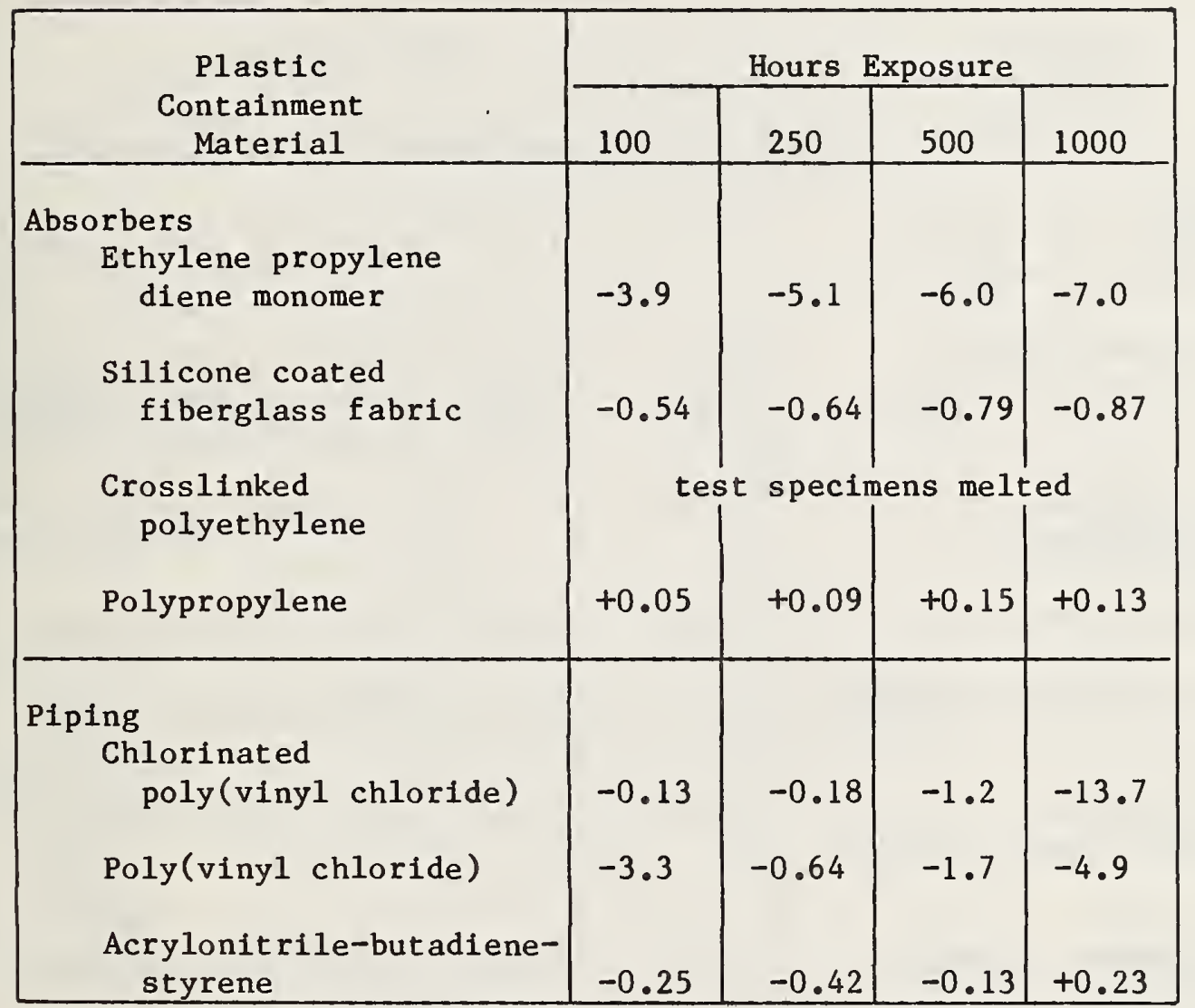

Note: These values are the average of three test specimens. 
Table 11. Specific Gravity After Heat Aging at $125^{\circ} \mathrm{C}$

\begin{tabular}{|c|c|c|c|c|c|}
\hline Plastic & Initial & \multicolumn{4}{|c|}{ Hours Exposure } \\
\hline $\begin{array}{c}\text { Containment } \\
\text { Material }\end{array}$ & $\begin{array}{l}\text { Specific } \\
\text { Gravity }\end{array}$ & 100 & 250 & 500 & 1000 \\
\hline $\begin{array}{l}\text { Absorbers } \\
\text { Ethylene propylene } \\
\text { diene monomer }\end{array}$ & 1.167 & 1.168 & 1.176 & 1.185 & 1.197 \\
\hline $\begin{array}{l}\text { Silicone coated } \\
\text { fiberglass fabric }\end{array}$ & $\begin{array}{l}1.514 \\
1.510 \\
1.510\end{array}$ & $\begin{array}{l}1.512 \\
1.492 \\
1.501\end{array}$ & $\begin{array}{l}1.505 \\
1.485 \\
1.482\end{array}$ & $\begin{array}{l}1.500 \\
1.489 \\
1.480\end{array}$ & $\begin{array}{l}1.482 \\
1.458 \\
1.435\end{array}$ \\
\hline $\begin{array}{l}\text { Crosslinked } \\
\text { polyethylene }\end{array}$ & 0.932 & & t spec & nen me & \\
\hline Polypropylene & 0.907 & 0.912 & 0.912 & 0.913 & 0.910 \\
\hline Polypropylene copolymer & 0.917 & 0.917 & 0.918 & 0.918 & 0.919 \\
\hline $\begin{array}{l}\text { Piping } \\
\text { Chlorinated } \\
\text { poly(vinyl chloride) }\end{array}$ & 1.574 & 1.574 & 1.575 & 1.573 & $\begin{array}{l}1.273 \\
1.387 \\
1.473\end{array}$ \\
\hline Poly(vinyl chloride) & 1.387 & 1.388 & 1.390 & 1.392 & 1.390 \\
\hline $\begin{array}{l}\text { Acrylonitrile-butadiene- } \\
\text { styrene }\end{array}$ & 1.032 & 1.032 & 1.034 & 1.039 & 1.047 \\
\hline
\end{tabular}

NOTE: These values are the average of three test specimens for all materials except silicone coated fiberglass and CPVC pipe at 1000 hours. 
Table 12. Hardness Change After Heat Aging at $125^{\circ} \mathrm{C}$

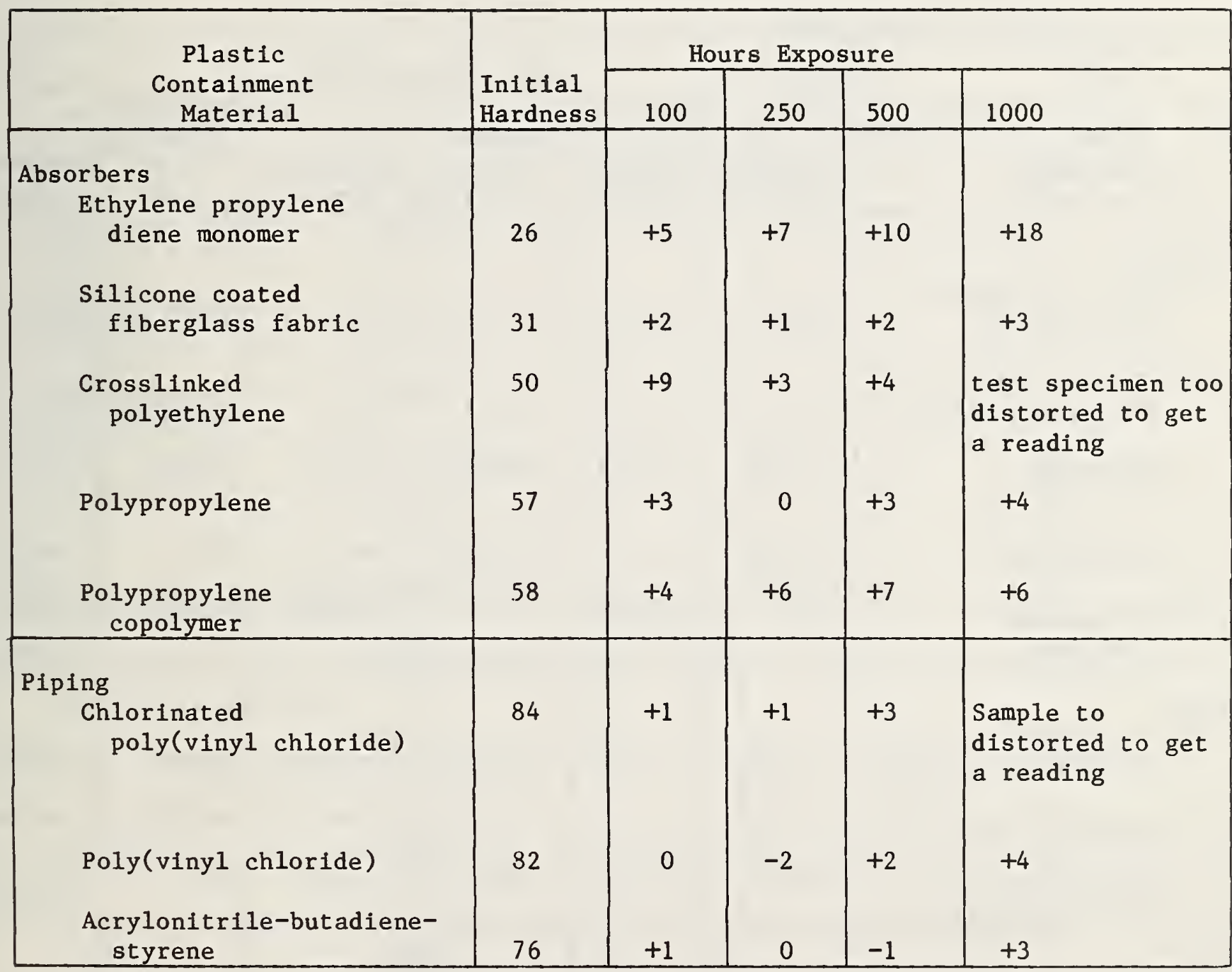

Hardness measured with D2240 Shore Durometer Type D2. A reading of \pm 3 graduations is significant. Reproducibility is \pm 2 graduations. 
Table 13. Weight Change (Percentage) After Immersion at Room Temperature in Heat Transfer Fluids for 7 Days

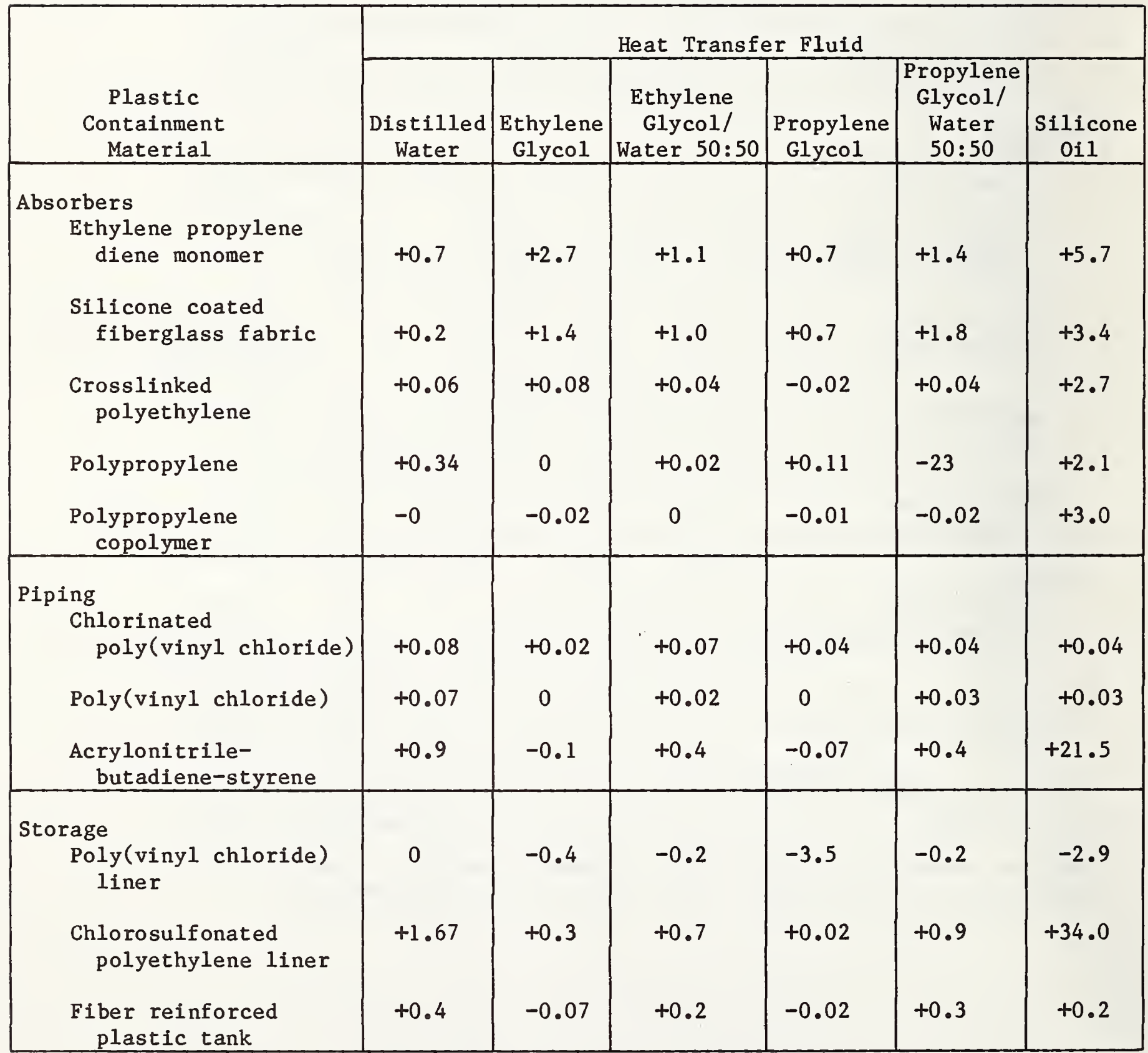


Table 14. Dimension Changes (Percentage) After Immersion at Room Temperature in Heat Transfer Fluids for 7 Days

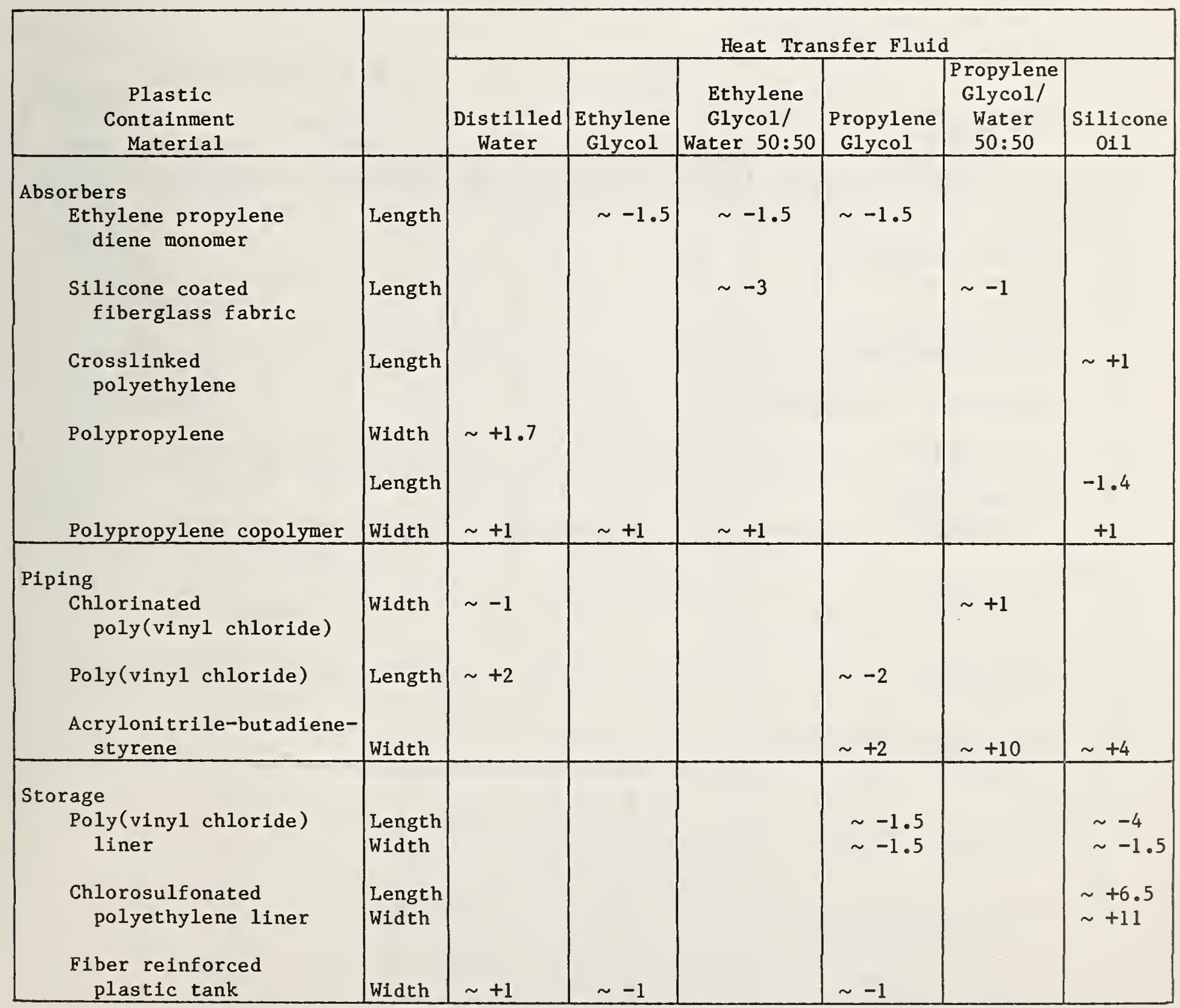

Note: Changes less than one percent are not listed. 
Table 15. Hardness After Immersion at Room Temperature in Heat Transfer Fluids for 7 Days

\begin{tabular}{|c|c|c|c|c|c|c|c|}
\hline & & \multicolumn{6}{|c|}{ Heat Transfer Fluid } \\
\hline $\begin{array}{c}\text { Plastic } \\
\text { Containment } \\
\text { Material } \\
\end{array}$ & $\begin{array}{l}\text { Initial } \\
\text { Hardness } \\
\end{array}$ & $\begin{array}{c}\text { Distilled } \\
\text { Water }\end{array}$ & $\begin{array}{c}\text { Ethylene } \\
\text { Glycol }\end{array}$ & $\begin{array}{c}\text { Ethylene } \\
\text { Glycol/ } \\
\text { Water } 50: 50 \\
\end{array}$ & $\begin{array}{c}\text { Propylene } \\
\text { Glycol }\end{array}$ & \begin{tabular}{|c|} 
Propylene \\
Glycol/ \\
Water \\
$50: 50$ \\
\end{tabular} & $\begin{array}{c}\text { Silice } \\
0 i 1\end{array}$ \\
\hline $\begin{array}{l}\text { Absorbers } \\
\text { Ethylene propylene } \\
\text { diene monomer }\end{array}$ & 66 & 74 & 66 & 75 & 76 & 74 & 75 \\
\hline $\begin{array}{l}\text { Silicone coated } \\
\text { fiberglass fabric }\end{array}$ & 81 & 84 & 85 & 85 & 85 & 84 & 87 \\
\hline Crosslinked polyethylene 2 & 50 & 50 & 51 & 51 & 50 & 50 & 46 \\
\hline Polypropylene 2 & 59 & 60 & 60 & 59 & 55 & 54 & 58 \\
\hline $\begin{array}{c}\text { Polypropylene } \\
\text { copolymer }{ }^{2}\end{array}$ & 49 & 45 & 46 & 50 & 51 & 45 & 54 \\
\hline $\begin{array}{l}\text { Piping } \\
\text { Chlorinated } \\
\text { poly(vinyl chloride) }\end{array}$ & 71 & 71 & 71 & 70 & 69 & 63 & 69 \\
\hline $\begin{array}{l}\text { Poly (vinyl } \\
\quad \text { chloride) }\end{array}$ & 65 & 53 & 54 & 54 & 52 & 53 & 56 \\
\hline $\begin{array}{l}\text { Acrylonitrile-butadiene- } \\
\text { styrene }\end{array}$ & 78 & 74 & 75 & 74 & 75 & 75 & 63 \\
\hline $\begin{array}{l}\text { Storage } \\
\text { Poly(vinyl chloride) } \\
\quad \text { liner }{ }^{2}\end{array}$ & 35 & 34 & 30 & 31 & 30 & 31 & 34 \\
\hline $\begin{array}{l}\text { Chlorosulfonated } \\
\text { polyethylene liner } 1\end{array}$ & 81 & 87 & 90 & 90 & 90 & 90 & 67 \\
\hline $\begin{array}{c}\text { Fiber reinforced } \\
\text { plastic tank }\end{array}$ & 69 & 73 & 71 & 70 & 72 & 72 & 70 \\
\hline
\end{tabular}

1 Hardness measured with D2240 Shore Durometer Type A2.

2 Hardness measured with D2240 Shore Durometer Type D2

3 Hardness measured with D785 Rockwell 15W.

4 Hardness measured with D785 Rockwell 30W. 
Table 16. Weight Change (Percentage) After Immersion at $70^{\circ} \mathrm{C}$ in Heat Transfer Fluids for 7 Days

\begin{tabular}{|c|c|c|c|c|c|c|}
\hline \multirow[b]{2}{*}{$\begin{array}{l}\text { Plastic } \\
\text { Containment } \\
\text { Material }\end{array}$} & \multicolumn{6}{|c|}{ Heat Transfer Fluid } \\
\hline & $\begin{array}{c}\text { Distilled } \\
\text { Water }\end{array}$ & $\begin{array}{c}\text { Ethylene } \\
\text { Glycol }\end{array}$ & \begin{tabular}{|c|} 
Ethylene \\
Glycol/ \\
Water 50:50 \\
\end{tabular} & $\begin{array}{c}\text { Propylene } \\
\text { Glycol }\end{array}$ & $\begin{array}{l}\text { Propylene } \\
\text { Glycol/ } \\
\text { Water } \\
50: 50 \\
\end{array}$ & $\begin{array}{c}\text { Silicone } \\
0 i 1\end{array}$ \\
\hline $\begin{array}{l}\text { Absorbers } \\
\text { Ethylene propylene } \\
\text { diene monomer }\end{array}$ & +3.2 & +4.3 & +2.1 & -0.5 & +2.3 & +19.5 \\
\hline Crosslinked polyethylene & +0.1 & -0.03 & +0.04 & -0.1 & +0.04 & +12.6 \\
\hline Polypropylene & +0.4 & +1.1 & +1.6 & +1.4 & +1.5 & +12.1 \\
\hline Polypropylene copolymer & +0.2 & +1.5 & +1.1 & +1.6 & +0.7 & +13.4 \\
\hline $\begin{array}{l}\text { Piping } \\
\text { Chlorinated } \\
\text { poly(vinyl chloride) }\end{array}$ & +0.3 & -0.06 & +0.1 & -0.1 & +0.2 & +24.6 \\
\hline Poly(vinyl chloride) & +0.2 & -0.05 & +0.1 & -0.1 & +0.2 & +2.5 \\
\hline $\begin{array}{l}\text { Acrylonitrile-butadiene- } \\
\text { styrene }\end{array}$ & +2.0 & -0.02 & +0.3 & +0.02 & +0.5 & +197 . \\
\hline
\end{tabular}


Table 17. Dimensional Changes (Percentage) After Immersion at $70^{\circ} \mathrm{C}$ in Heat Transfer Fluids for 7 Days

\begin{tabular}{|c|c|c|c|c|c|c|c|}
\hline \multirow[b]{2}{*}{$\begin{array}{c}\text { Plastic } \\
\text { Containment } \\
\text { Material } \\
\end{array}$} & & \multicolumn{6}{|c|}{ Heat Transfer Fluid } \\
\hline & & $\begin{array}{c}\text { Distilled } \\
\text { Water }\end{array}$ & $\begin{array}{c}\text { Ethylene } \\
\text { Glycol }\end{array}$ & $\begin{array}{c}\text { Ethylene } \\
\text { Glycol/ } \\
\text { Water } \\
50: 50 \\
\end{array}$ & $\begin{array}{c}\text { Propylene } \\
\text { Glycol }\end{array}$ & \begin{tabular}{|c|} 
Propylene \\
Glycol/ \\
Water \\
$50: 50$ \\
\end{tabular} & $\begin{array}{c}\text { Silicone } \\
\text { Oil }\end{array}$ \\
\hline $\begin{array}{l}\text { Absorbers } \\
\text { Ethylene propylene } \\
\text { diene monomer }\end{array}$ & $\begin{array}{l}\text { Length } \\
\text { Width }\end{array}$ & $\sim+1$ & $\begin{array}{l}\sim+1 \\
\sim+2.3\end{array}$ & $<-1$ & & $\sim+1.3$ & $\begin{array}{l}\sim+2.9 \\
\sim+4.7\end{array}$ \\
\hline Crosslinked polyethylene & $\begin{array}{l}\text { Length } \\
\text { Width }\end{array}$ & $\sim+1.3$ & $\sim-1$ & & $<-1$ & $\begin{array}{l}<-i \\
\sim+2\end{array}$ & $\begin{array}{l}\sim+4 \\
\sim+7\end{array}$ \\
\hline Polypropylene & $\begin{array}{l}\text { Length } \\
\text { Width }\end{array}$ & & & & & & $\begin{array}{l}\sim+2.5 \\
\sim+3\end{array}$ \\
\hline Polypropylene copolymer & $\begin{array}{l}\text { Length } \\
\text { Width }\end{array}$ & & & & & & $\begin{array}{r}\sim+2.3 \\
\sim \\
\sim\end{array}$ \\
\hline $\begin{array}{l}\text { Piping } \\
\text { Chlorinated } \\
\text { poly(vinyl chloride) }\end{array}$ & $\begin{array}{l}\text { Length } \\
\text { Width }\end{array}$ & & & & & & $\begin{array}{l}\sim+2 \\
\sim+4.5\end{array}$ \\
\hline Poly(vinyl chloride) & Length & & & $<-1$ & & $<-1$ & \\
\hline $\begin{array}{l}\text { Acrylonitrile-butadiene- } \\
\text { styrene }\end{array}$ & $\begin{array}{l}\text { Length } \\
\text { Width }\end{array}$ & & & & & & $\begin{array}{l}\sim+7 \\
\sim+19\end{array}$ \\
\hline
\end{tabular}

NOTE: Changes of less than one percent are not shown. 


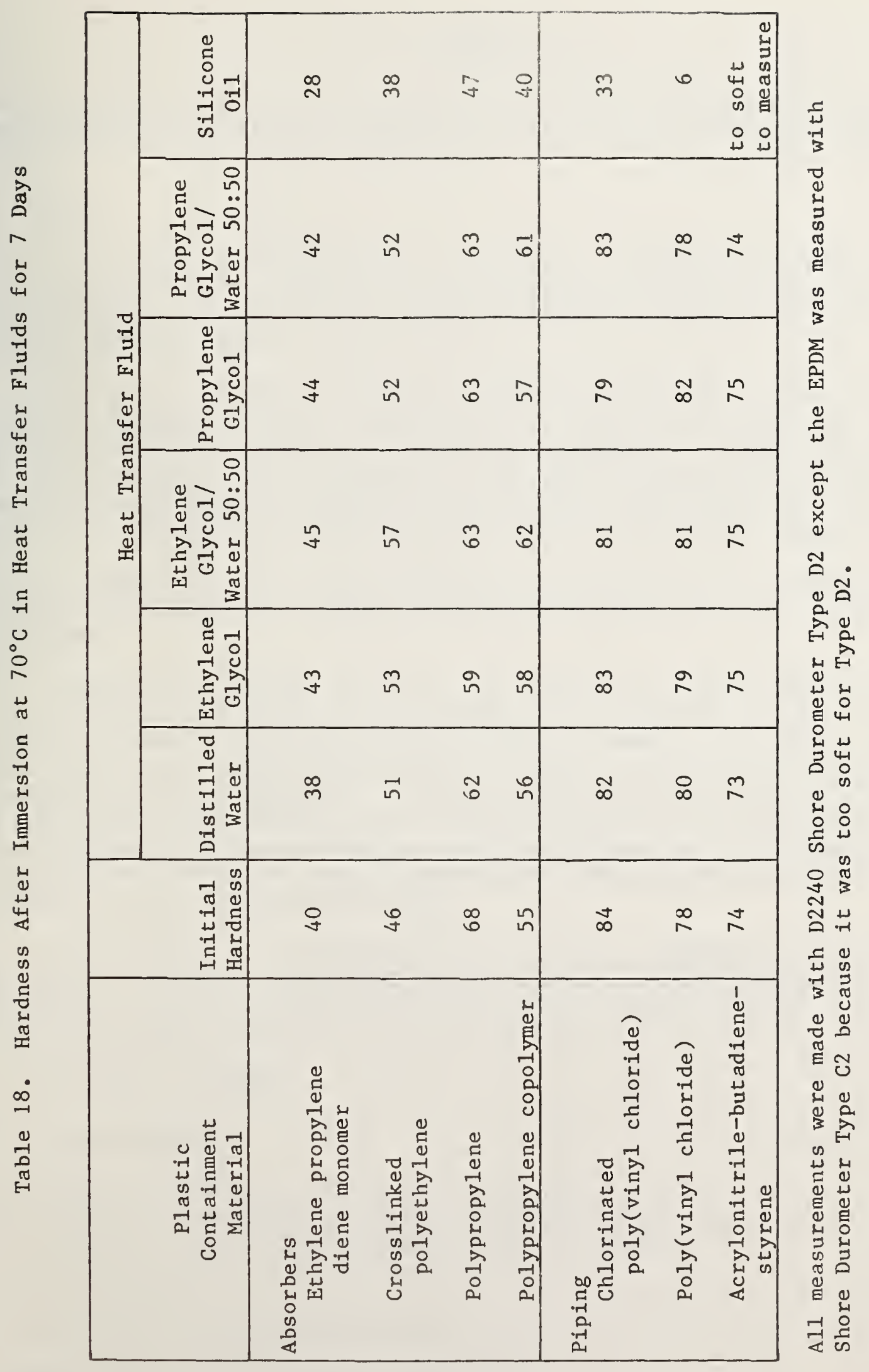



APPENDIX A

PROPOSED STANDARD PRACTICE FOR SCREENING POLYMERIC CONTAINMENT MATERIALS FOR THE EFFECTS OF HEAT AND HEAT TRANSFER FLUIDS IN SOLAR HEATING AND COOLING SYSTEMS

1. SCOPE

1.1 This practice is intended for evaluation of candidate polymeric materials for containment applications in solar heating and cooling systems by determining the effects of heat and heat transfer fluids on selected mechanical and dimensional properties.

1.2 This practice contains both environmental exposure procedures and property measurement tests. The exposure procedures are relatively short-term exposures intended to screen out unsuitable materials. Procedures are included for exposure (1) to heat representative of potential application temperatures and (2) to heat transfer liquids. The property measurement tests included are appearance, dimensions, hardness, mass, flexural and tensile properties.

1.3 The effects of the exposure procedures are evaluated by comparison of the initial material property values with those obtained after the exposure procedures.

1.4 This practice applies to, but is not limited to, the evaluation of polymeric materials intended for the following containment applications: transport piping, solar collector absorbers, storage tanks, storage tank liners, pumps and valves. The practice shall not apply to the testing of organic coatings or glazing materials. This practice also does not apply to evaluation of components, subassemblies, and assemblies except where such fabricated articles may provide the specimens for materials screening. For example, rubber hose should be evaluated using specification D3952, and rubber seals should be evaluated using specification D 3832.

1.5 This standard may include the use of hazardous materials, operations, and equipment. It is the responsibility of whoever uses this standard to establish appropriate safety practices and to determine the applicability of regulating limitations prior to use.

\section{APPLICABLE DOCUMENTS}

\subsection{ASTM STANDARDS}

D 412 Tests for Rubber Properties in Tension 1

D 543 Test for Resistance of Plastics to Chemical Reagents ${ }^{2}$

D 573 Test for Rubber-Deterioration in an Air Oven 1

1 Annual Book of ASTM Standards, Part 37.

2 Annual Book of ASTM Standards, Part 35. 
D 618 Conditioning Plastics and Electrical Insulating Materials for Testing ${ }^{2}$

D 638 Test for Tensile Properties of Plastics ${ }^{2}$

D 790 Tests for Flexural Properties of Plastics and Electrical Insulating Materials ${ }^{2}$

D 882 Tests for Tensile Properties of Thin Plastic Sheeting 2

D 883 Definitions of Terms Relating to Plastics ${ }^{2}$

D 1042 Tests for Linear Dimensional Changes of Plastics Under Accelerated Service Conditions ${ }^{2}$

D 1181 Test for Warpage of Sheet Plastics ${ }^{2}$

D 1204 Test for Linear Dimensional Changes of Nonrigid Thermoplastic Sheeting or Film at Elevated Temperatures ${ }^{2}$

D 1415 Test for Rubber Property - International Hardness 1

D 1556 Definitions of Terms Relating to Rubberl

D 2240 Test for Rubber Property - Durometer Hardness 1

D 3832 Specification for Rubber Seals Contacting Liquids in Solar Energy Systems

D 3952 Specification for Rubber Hose Used in Solar Energy Systems

E 632 Practice for Developing Short-Term Accelerated Tests for Prediction of the Service Life of Bullding Components and Materials ${ }^{3}$

E 772 Definitions of Terms Relating to Solar Energy Conversion 4

F 412 Definitions of Terms Relating to Plastic Piping 5

\section{SIGNIFICANCE AND USE}

3.1 Containment materials in solar heating and cooling systems are exposed for long periods to heat and to heated fluids. Such long-term exposures may alter the key properties of polymeric containment materials sufficiently to jeopardize the performance and durability of components made using the materials. This practice is to be used to provide the data to screen out materials unsuitable for use at the test temperatures or with the heat transfer fluids, and to provide a basis for establishing a relative ranking of the resistance of candidate materials to heat and to heat transfer fluids.

\subsection{ELEVATED TEMPERATURES}

3.2.1 In solar energy systems the various containment materials are exposed to elevated temperatures. The actual temperatures vary depending on (1) the specific contalnment application, (2) type of system, (3) solar system operation,

1 Annual Book of ASTM Standards, Part 37.

2 Annual Book of ASTM Standards, Part 35.

3 Annual Book of ASTM Standards, Part 18.

4 Annual Book of ASTM Standards, Part 41.

5 Annual Book of ASTM Standards, Part 34. 
and (4) weather. Continuous in-service temperatures occur during typical operation of the system. Stagnation temperatures occur when the sun is shining but the system is not operating to remove heat from the collectors. Certain components, such as absorbers, are subject to maximum temperature elevation during stagnation. For other components, such as storage tanks, stagnation conditions would not cause their temperatures to rise significantly above the continuous in-service temperatures.

3.2.2 Polymeric materials exposed to heat undergo many types of physical, mechanical, and chemical changes. The severity of the exposures in both time and temperature determines the extent and type of change. A polymeric material is not necessarily degraded by exposure to elevated temperatures, but may be unchanged or improved if the exposure is short-term. However, extended periods of exposure of polymers to elevated temperatures will generally cause some degradation, with progressive change in physical properties.

3.2.3 Generally, short exposures at elevated temperatures may drive out volatiles such as moisture, solvents, or plasticizers, relieve molding stresses, advance the cure of thermosets, and cause some change in the color of the polymer or coloring agent or both. Normally, additional shrinkage should be expected with loss of volatiles, advance in polymerization, or relief of molding stresses.

3.2.4 Some polymeric materials may become brittle after exposure at elevated temperatures due to loss of plasticizers or to thermal degradation. Other types of polymers become soft and sticky, either due to absorption of volatilized plasticizer or due to breakdown of the polymer.

3.2.5 Effects of exposure nay be quite variable, especially when specimens are exposed for long intervals of time. Moreover they are cumulative with time. Factors that affect the reproducibility of data are the degree of temperature control of the enclusure, the type of molding, type of cure, humidity of the oven room, air velocity over the specimen, and period of exposures.

3.2.6 The changes in the mechanical and dimensional properties of polymeric containment materials caused by elevated temperatures may be sufficient to discourage the use of a particular material for one application, but not for others. Since this practice may be used to evaluate materials for components and applications having widely different in-service temperatures, both the test temperatures chosen and the results of testing need to be examined critically and with respect to application, exposure temperatures and times expected. Different heat stability test temperatures are recommended for materials intended for different applications in solar heating and cooling systems.

\subsection{CHEMICAL COMPATIBILITY}

3.3.1 Inertness of polymeric containment materials in contact with heat transfer fluids is essential. This practice may be used to evaluate the shortterm chemical compatibility of polymeric containment materials with aqueous or organic based heat transfer fluids. Care must be taken to select appropriate 
test conditions for a given containment material, i.e., the different heat transfer fluids to which the material may realistically be exposed; the maximum continuous temperature to which the fluid will be raised; and the duration of exposure. Test results are indicative of the performance of the containment material only as part of a polymeric material/fluid pair.

3.3.2 Taken by itself, performance in these laboratory test procedures does not necessarily provide an adequate basis for acceptance or rejection of a particular polymeric material/fluid pair in solar heating and cooling systems. For containment applications involving continuous immersion, the data obtained in short time tests are of interest only in eliminating the most unsuitable materials or indicating a probable relative order of resistance to chemical reagents.

3.4 Material property changes may be used to evaluate the effect of heat and heat transfer fluids on polymeric containment materials. The degree of change observed will depend on the property measured. Different properties do not necessarily change at the same rate. Ultimate properties such as strength or elongation at break are generally more sensitive to degradation than are bulk properties such as modulus.

3.4.1 Permanent changes in the size, shape, mass, and appearance of a polymeric material may result from exposure to heat and to aqueous- and organic-based liquids. A molded or extruded material may discolor, expand, shrink, or warp. Changes in shape or dimensions may induce additional stresses in the components in a system or they may make a component unsuitable for use.

3.4.2 Tensile properties are the most important indication of strength in a material when it is subjected to forces which tend to pull it apart. Tensile properties include tensile strength, percent elongation at yield and rupture, and the modulus of elasticity.

3.4.3 Flexural properties reflect the ability of a material to withstand rupture when a bending stress is applied at the center of a beamlike specimen supported at both ends. Flexural properties include flexural strength, tangent or secant modulus of elasticity and flexural yield strength. Flexural properties are especially sensitive to changes that occur in specimen surfaces.

3.4.4 Indentation hardness as determined by a durometer is a measure of the ability of a material to resist penetration and scratching when an indentor of specified geometry is forced into the material under specific conditions. The indentation hardness of elastomeric materials, in particular, is especially sensitive to changes that occur in specimen surfaces.

3.5 This practice is designed to facilitate the rejection of unsuitable materials from the list of candidate materials. This practice is an expedient screening procedure to rapidly identify those candidate polymeric materials which are adversely affected by heat or are incompatible with a particular heat exchange fluid in question at particular temperatures of operation. Numerous other aspects of performance and durability may also affect the choice of 
suitable materials (for example, creep resistance, low temperature imbrittlement, impact strength, and ultraviolet light stability), depending upon the end-use service.

3.6 This practice is not a comprehensive methodology for determining the most suitable materials for specific components and applications. Additional exposure and property measurement tests are recommended to complete the process of selecting a candidate material, especially when such tests more closely simulate field service conditions and when candidate polymeric materials are fabricated as components of actual solar heating and cooling systems. Other tests for screening and evaluative purposes that may be performed are listed in the Appendix (Note 1).

Note 1: Components in solar heating and cooling systems experience different $\overline{\text { levels }}$ of environmental exposure and mechanical stresses. Therefore, candidate materials for each application should be evaluated with the severity and completeness demanded by the ultimate application. Key properties of a containment material should be determined following exposure to maximum levels or ranges of sunlight, temperature, and moisture that are typical of actual service conditions. Table 1 of Practice E632 contains a comprehensive outline of factors that are expected to affect the durability of materials and components when subjected to outdoor weathering conditions.

3.7 Insufficient data exist at this time to demonstrate correlations between the results of short-term laboratory evaluations and field performance.

\section{TERMINOLOGY}

\subsection{DEFINITIONS HAVING GENERAL APPLICATION:}

4.1.1 Plastics - Definition D883, Definitions of Terms Relating to Plastics

4.1.2 Rubber - Definition D1566, Definitions of Terms Relating to Rubber and Rubber-Like Materials

4.1.3 Solar Energy - Definition E772, Definitions of Terms Relating to Solar Energy Conversion

4.1.4 Plastic Pipe - Definition F412, Definitions of Terms Relating to Plastic Piping Systems

\subsection{DESCRIPTION OF TERMS:}

4.2.1 Heat Transfer Fluid - This term as used in this practice pertains to both circulating heat exchange liquids and heat storage liquids.

4.2.2 Polymeric Materials - Includes rigid and nonrigid plastics and elastomers as single components, laminates, foams, and other polymer-matrix composites. 
4.2.3 Containment Material - Any material comprising a component within a solar energy system intended to hold, store, convey, or otherwise come into direct contact with a heat transfer fluid.

\section{MATERIALS}

5.1 Any polymeric material may be selected for evaluation. The material must be capable of being described adequately to permit duplication of the test.

5.2 Any heat transfer fluid may be selected for assessing its compatibility with the polymer. The heat transfer fluid should be capable of being described chemically as to its basic components and their concentrations. The presence or absence of minor components which may affect the interactions with the polymer shall be noted. Commercially available fluids may be described by proprietary designation.

\section{CONDITIONING}

\subsection{CONDITIONING}

Condition all test specimens at $23^{\circ} \pm 2^{\circ} \mathrm{C}\left(73^{\circ} \pm 4^{\circ} \mathrm{F}\right)$ and $50 \pm 5$ percent relative humidity for not less than $\overline{4} 0$ hours prīor to test or measurement in accordance with Procedure A of Method D618.

\subsection{TEST CONDITIONS}

Conduct all tests in the standard laboratory atmosphere of $23^{\circ} \pm 2^{\circ} \mathrm{C}\left(73^{\circ} \pm\right.$ $4^{\circ} \mathrm{F}$ ) and $50+5$ percent relative humidity (Note 2 ) unless otherwise specified in the methods.

Note 2: In actual practice, plastic and elastomeric containment materials must have acceptable physical properties over a wide range of temperature and humidity conditions. Where it is possible to conduct tensile tests above and below ambient conditions, investigators are encouraged to do so.

\section{TEST SPECIMENS}

7.1 The minimum number of specimens needed for each of the property tests (Note 3 ) is specified in Table Al. The type of test specimens shall be in accordance with the ASTM test method for the specific property to be determined.

Note 3: Tensile and flexural property tests are critically dependent on specimen anisotropy. Where anisotropy is known to be present (injection moldings and composite materials such as laminates) or suspected (thin wall extrusions), tensile and flexural properties need to be measured for two of the three principle axes of the specimen.

7.2 Specinens may be cut from sheets, plates, or molded shapes (Note 4) or may be molded to the desired finished dimensions. 
TABLE AI

Summary of Property and Exposure Tests

Numbers in Columns Refer to the Minimum Number of Specimens Required for Each of the Tests

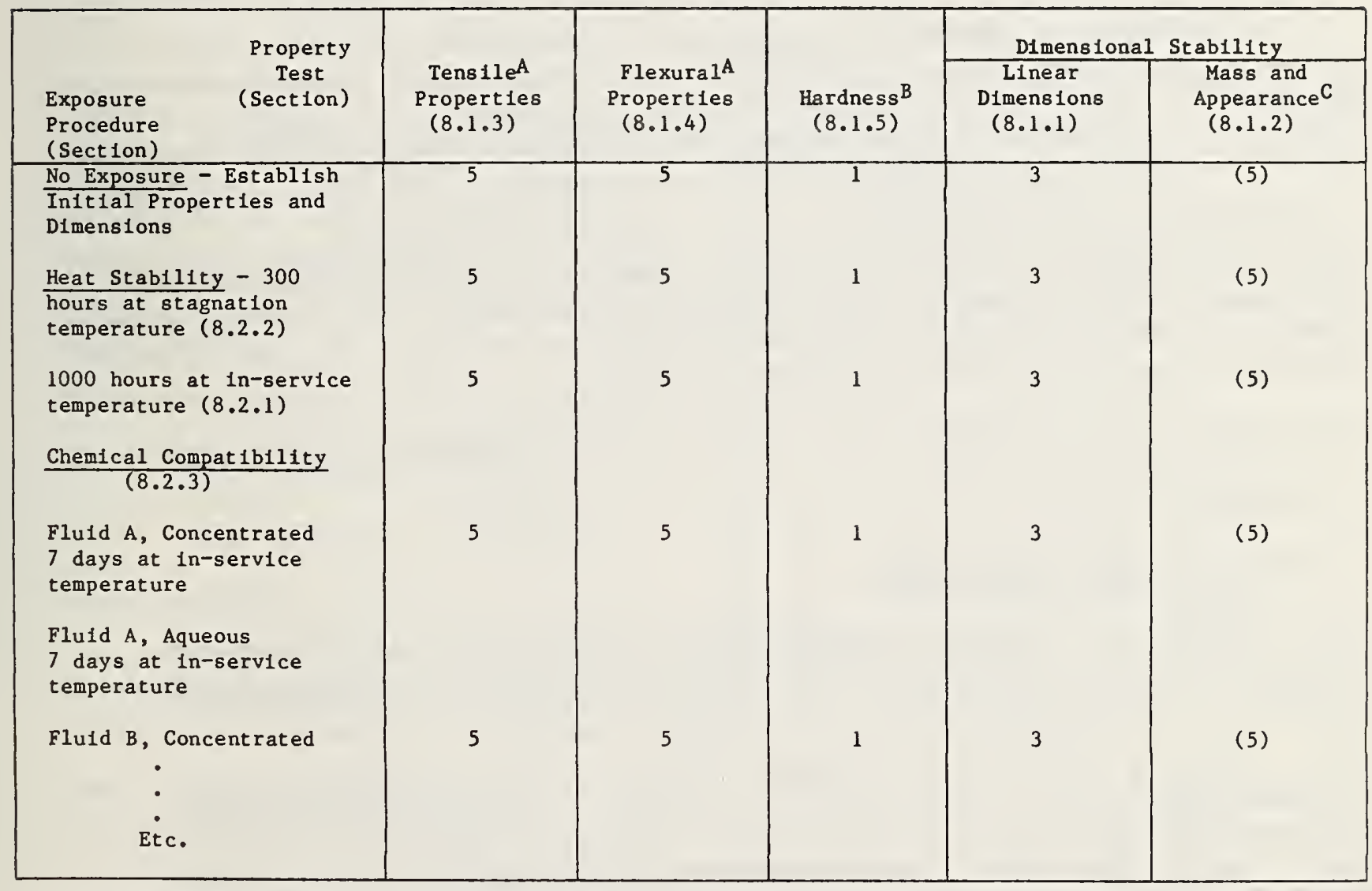

A Five specimens are suffictent for testing lsotropic specimens. Anisotropic moldings require a minimum of ten specimens per set, five specimens for each axis of anisotropy.

B Three measurements required per specimen.

C Undeformed tensile spectmens may be used. 
Note 4: Although fabricated articles may be used as a source of specimens, it may be impracticable to determine their tensile and flexural properties if the articles present complex profiles of varying thicknesses.

The tensile and flexural properties tests demand that specimens possess uniform cross-sectional areas to insure good precision and repeatability of results.

7.3 The geometry of the test specimens used to evaluate the properties of polymeric containment materials shall be in accordance with the ASTM method for the specific property to be determined. The thickness of the specimens may be either as specified in the appropriate test method, or equivalent to the thickness of material in an intended component or assembly. The latter is preferred.

7.4 Certain materials are susceptible to edge effects when exposed to a variety of chemical reagents. Since edges are not normally exposed to the environment in the intended field application, specimens to be immersed in heat transfer fluids may have the edges sealed prior to testing. The sealing method and sealant must not distort the test results.

7.5 Separate test specimens shall be used for the physical property tests.

8. METHODS OF TEST

\subsection{PROPERTY MEASUREMENT TESTS}

8.1.1 Dimensional Stability - Determine the dimensional stability of rigid and semirigid materials according to Method D1042 and for nonrigid materials according to Method D1204.

8.1.2 Mass and Appearance - Determine changes in mass and appearance according to Method D543.

8.1.3 Tensile Properties - Determine the tensile properties of rigid and semirigid plastic materials according to Method D638 using speed B and Type IV specimens 6 . Use Method D882 for flexible sheet plastic materials or Method D412 for elastomeric materials.

8.1.4 Flexural Properties - Determine the flexural properties of rigid and semirigid plastic macerials according to Method D790.

8.1.5 Hardness - Determine hardness of elastomers according to either Method D1415 or Method D2240 using Type A durometer ${ }^{7}$. Determine hardness of rigid and semirigid plastic materials according to Method D2240 using a Type D durometer.

6 Type C die may be used to produce specimens from both plastic and elastomeric materials.

7 Method D1415 (International Hardness) is the more commonly employed method for purposes of specification. 


\subsection{EXPOSURE PROCEDURES}

8.2.1 Continuous In-Service Temperatures - Using an air-circulating oven and the procedure described in Method D573, expose one set of test specimens for 1000 hours to the appropriate test temperature in Table A2. The recommended temperatures in Table A2 approximate in-service temperatures in a variety of typical solar systems incorporating flat-plate collectors

\begin{tabular}{|c|c|}
\hline \multicolumn{2}{|c|}{ Table A2. Temperatures for Continuous In-Service Screening } \\
\hline Polymeric Material Application & Recommended Test Temperature \\
\hline Flat-plate Absorber Panels - glazed & $70^{\circ} \pm 2^{\circ} \mathrm{C}\left(158^{\circ} \pm 4^{\circ} \mathrm{F}\right)$ \\
unglazed & $43^{\circ} \pm 2^{\circ} \mathrm{C}\left(110^{\circ} \pm 4^{\circ} \mathrm{F}\right)$ \\
Transport piping, valves, fittings, & $70^{\circ} \pm 2^{\circ} \mathrm{C}\left(158^{\circ} \pm 4^{\circ} \mathrm{F}\right)$ \\
pumps - within collector & $43^{\circ} \pm 2^{\circ} \mathrm{C}\left(110^{\circ} \pm 4^{\circ} \mathrm{F}\right)$ \\
Storage tanks, liners & $70^{\circ} \pm 2^{\circ} \mathrm{C}\left(158^{\circ} \pm 4^{\circ} \mathrm{F}\right)$ \\
\hline
\end{tabular}

For materials intended for systems incorporating collectors other than flat-plate, the maximum anticipated temperature shall be used.

8.2.2 Stagnation Temperatures - Polymeric materials to be used to fabricate components, such as absorbers, headers, valves, and fittings, will be subject to the maximum temperature elevation during stagnation.

Expose these materials to heat for 300 hours at the maximum expected stagnation tion temperature (Note 5). The stagnation temperature shall be no lower than $45^{\circ} \mathrm{C}\left(81^{\circ} \mathrm{F}\right.$ ) above the maximum in-service temperature (Note 6 ).

Note 5: No single temperature or procedure can duplicate the range of temperatures and environmental conditions to which absorbers may be exposed during stagnation conditions. Moreover, maximum stagnation temperatures, whether determined experimentally or calculated from theoretical models, will depend upon a number of collector design factors, which include whether or not the collector is glazed and whether or not the design incorporates mechanical or other means for limiting temperature during non-operational conditions. Therefore, the temperature approximating the stagnation mode must be selected rationally on the basis of intended application and field or simulated temperature and solar irradiance measurements.

Note 6: Solar collector performance data published by such collector testing and certifying agencies as California Energy Commission and Florida Solar Energy Center can provide guidance for selecting stagnation temperatures. The 
performance curves and data listed by the above for six commercial collectors indicate that under such conditions as $330 \mathrm{Btu} / \mathrm{ft}^{2} \mathrm{hr}$ irradiance and $41^{\circ} \mathrm{C}$ $\left(105^{\circ} \mathrm{F}\right)$ ambient temperature the stagnation temperature for unglazed and glazed collectors range between $75-88^{\circ} \mathrm{C}\left(168-191^{\circ} \mathrm{F}\right)$ and $90-169^{\circ} \mathrm{C}\left(194-336^{\circ} \mathrm{F}\right)$, respectively.

\subsubsection{Chemical Compatibility}

8.2.3.1 Evaluate the chemical compatibility according to Method D543 using a seven day exposure. Substitute the applicable heat transfer fluids, including distilled or deionized water, for the standard reagents listed in Method D543. For heat transfer fluids commonly used as aqueous solutions, the test reagents shall include both an undiluted fluid and the fluid diluted for in-service use. Select the test temperature from the list of test temperatures given in Table A2 of Sec. 8.2.1. Use higher test temperatures in evaluating the compatibility of polymer/fluid pairs for systems having concentrating collectors.

8.3.3.2 Particular attention should be exercised in handling materials, fluids, or polymer/fluid pairs that can be hazardous to laboratory personnel. The flammability, vapor pressures, and toxicity of the heat transfer fluid shall be known prior to initiation of testing and appropriate precautionary measures shall be taken to insure the safety of all personnel.

\section{PROCEDURE}

9.1 Prepare an adequate number of test specimens for the property tests and exposure procedures to be performed. As a minimum, this shall consist of the number shown in Table Al. The preferred testing sequence is shown in Figure Al.

\subsection{Condition the test specimens according to Sec. 6.1.}

9.3 Measure linear dimensions (Sec. 8.1.1), mass and appearance (Sec. 8.1.2), tensile properties (Sec. 8.1.3), flexural properties (Sec.8.1.4), and hardness (Sec. 8.1.5) of one set of test specimens to establish properties of the polymeric containment material. Record visual surface appearance characteristics, including color, gloss, texture, etc.

9.4 Expose one set of test specimens to the heat stability procedure for continuous in-service temperatures (Sec.8.2.1).

9.5 Measure linear dimensions, mass and appearance, tensile properties, flexural properties, and hardness of the test specimens from 9.4. Record visible surface changes, including discoloration, tackiness, loss of apparent gloss, pitting, cracking, swelling, and shrinkage.

9.6 Expose another set of test specimens to the heat stability procedure for stagnation temperatures (Sec.8.2.2).

9.7 Make measurements and observations as in 9.5 on test specimens from 9.6. 


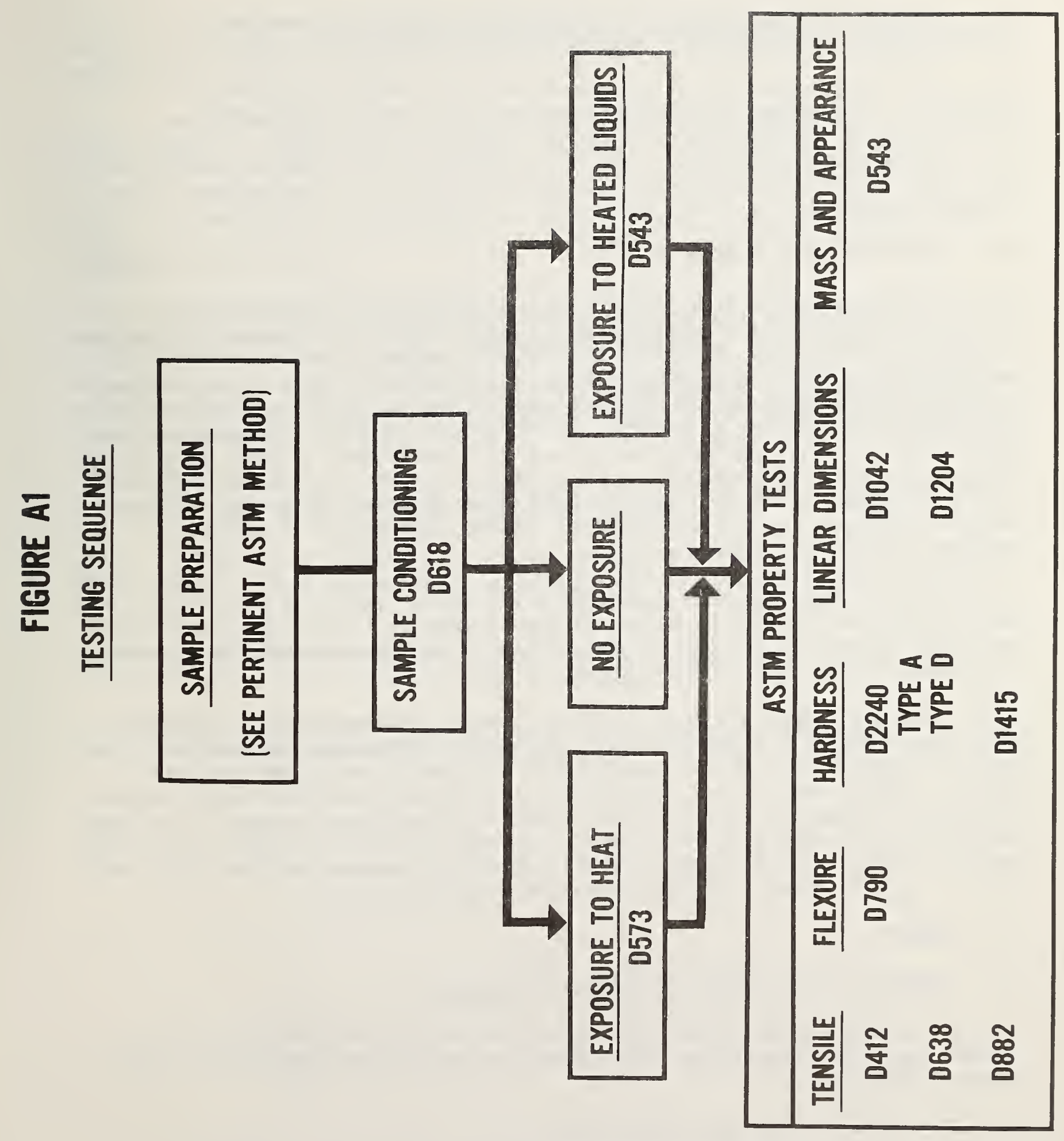


9.8 Expose a separate set of test specimens to each heat transfer fluid included in the chemical compatibility procedure (Sec. 8.2.3).

9.9 Make measurements and observations as in 9.5 on test specimens from 9.8. Also record any visible changes in the heat transfer fluid.

9.10 Express the deterioration of each property by the difference between the measurements made before and after each exposure as a percentage of the original property.

\section{INTERPRETATION OF RESULTS}

10.1 No acceptance or failure criteria are proposed, as the intention of this practice is to standardize testing and screening procedures for polymeric containment materials. It may be helpful with regard to materials selection and development efforts to adopt a general definition of failure as it appears elsewhere in these standards. Failure due to heat or due to contact with chemical reagents is defined as a change in mechanical property, dimension, weight, appearance, or other property that alters the containment material to a degree that is no longer acceptable for the service in question. Failure may result from blistering, cracking, loss of plasticizer or other soluble or volatile material that may cause embrittlement, warpage, shrinkage, or change in necessary mechanical properties.

10.2 It is recommended that, whenever practicable, candidate plastic and elastomeric containment materials should undergo no nore than 25 percent reduction in tensile strength or hardness and change permanently by no nore than 3 percent in linear dimensions.

10.3 Polymeric materials differ widely in their responses to environments which cause chemical degradation and reduction in molecular orientation. The rate of change with time (or temperature) of a key property may be of far greater significance than a single value determined at an arbitrarily selected condition. A graphical plot of test results for specimens exposed to the same elevated temperature but for different tines will indicate whether a-particular material will approach constant tensile strength, hardness modulus, etc., with time or will continue to deteriorate as the test progresses.

\section{REPORT}

11.1 The test report shall include the following:

11.1.1 Identification of the plastic or elastomeric containment material by standard specification (where applicable), by proprietary designation or by chemical analysis.

\subsubsection{Details of specimen preparation.}

11.1.3 For linear dimensional stability, the test specimen size and the average percentage change in linear dimensions following exposure to heat and to heat transfer fluids. 
11.1.4 For tensile properties prior to and following exposure to heat and to heat transfer fluids, the information necessary to complete the report in Methods D638, D882, or D412.

11.1.5 For flexural properties prior to and following exposure to heat and to heat transfer fluids, the information necessary to complete the report in Method D790.

11.1.6 For durometer hardness prior to and following exposure to heat and to heat transfer fluids, the information necessary to complete the report in Methods D2240 or D1415.

11.1.7 For the heat stability test, the temperature and duration of the test for continuous in-service conditions and for stagnation conditions.

11.1.7.1 The procedure for selecting the stagnation test temperature should be described and should include a record of temperature, solar irradiance, and other pertinent measures.

11.1.8 For the chemical compatibility test Method D543, the temperature and duration of each test, if longer than seven days.

11.1.8.1 The heat transfer fluids selected should be identified by standard specification (where applicable), by proprietary designation, or by chemical analysis.

11.1.9 Description of visible and mass changes in test specimens following exposure to heat and to heat transfer fluids.

11.1.9.1 Description of visible changes (color, turbidity, residue, etc.) in heat exchange fluid at the end of each test. 
APPENDIX

XI Supplementary Tests

XI.1
Xroperty Measurement Tests -- General
XI.1.1 Brittleness Temperature
$\begin{array}{ll}\text { D746 Brittleness Temperature of Plastics and Elastomers by Impact } \\ \text { D1790 Brittleness Temperature of Plastic Film by Impact }\end{array}$

XI.1.2 Chemical Resistance

C581 Chemical Resistance of Thermosetting Resins Used in Glass Fiber Reinforced Structures

XI.1.3 Coefficient of Expansion

D696 Coefficient of Linear Thermal Expansion of Plastics Creep

XI.1.4 Creep

D2990 Tensile, Compressive and Flexural Creep and Creep-Rupture of Plastics

XI.1.5 Density

D792 Specific Gravity and Density of Plastics by Displacement

XI.1.6 Heat Distortion Temperature

D1637 Heat Distortion Temperature of Plastic Sheeting and Film Under Tensile Load

XI.1.7 Impact Resistance

D256 Methods of Test for Impact Resistance of Plastics and Electrical Insulating Materials

D3029 Impact Resistance of Rigid Plastic Sheeting or Parts by Means of a Tup (Falling Weight)

XI.1.8 D785 Test for Rockwell Hardness of Plastics and Electrical Insulating Materials

XI.1.9 Stiffness

D747 Method of Test for Stiffness of Plastics by Means of a Cantilever Beam

D790 Flexural Properties of Plastics and Electrical Insulating Materials 
XI.1.10 Tensile and Elongation Properties

D1708 Method of Test for Tensile Properties of Plastics by Use of Microtensile Specimens

D2289 Method of Test for Tensile Properties of Plastics at High Speeds

XI.2 Property Measurement Tests -- Specific Plastics and Plastic Types

D1939 Residual Stresses in Extruded and Molded ABS

D3296 Dimensional Stability of FEP Plastic Tubing

D1547 Dimensional Stability of Extruded Methacrylate Sheet

D1693 Environmental Stress Cracking of Ethylene Plastics

D2115 Thermal Stability of PVC by Discoloration from Oven Heat Exposure

D3012 Thermal Oxidative Stability of Polypropylene to Heat and Air

D2445 Thermal Oxidative Stability of Polypropylene Heat and Oxygen 
NBS-114A (REV. $2 \cdot 8 \mathrm{C}$

\begin{tabular}{|c|c|c|c|}
\hline $\begin{array}{c}\text { U.S. DEPT. OF COMM. } \\
\text { BIBLIOGRAPHIC DATA } \\
\text { SHEET (See instructions) }\end{array}$ & $\begin{array}{l}\text { 1. PUBLICATION OR } \\
\text { REPORT NO. }\end{array}$ & 2. Performing Organ. Report No. & 3. Publication Date \\
\hline 4. & & & \\
\hline
\end{tabular}

4. TITLE AND SUBTITLE

Solar Energy Systems - Standards for Screening Plastic Containment Materials

5. AUTHOR(S)

Elizabeth J. Clark, Catherine D. Kelly and Willard E. Roberts

6. PERFORMING ORGANIZATION (If joint or other than NBS, see instructions)

NATIONAL BUREAU OF STANDARDS

DEPARTMENT OF COMMERCE

WASHINGTON, D.C. 20234

9. SPONSORING ORGANIZATION NAME AND COMPLETE ADDRESS (Street, City. Stote, ZIP)

U.S. Department of Energy

Office of Solar Heat Technologies

Active Heating and Cooling Division

Washington, DC 20585

10. SUPPLEMENTARY NOTES

Document describes a computer program; SF-185, FIPS Software Summary, is attached.

11. ABSTRACT (A 200-word or less factual summary of most significant information. If document includes a significant bibliography or literature survey, mention it here)

Plastic materials are being chosen more frequently for various applications in solar energy systems. Problems with materials in solar systems have indicated a need for standards to assess the performance and durability of the materials. In this investigation laboratory studies have been performed to obtain data needed to develop standards to screen plastic containment materials for the effects of heat and for compatibility with heat transfer fluids. Five absorbers, three plastic pipe materials, and three plastics used in storage applications were included. They were evaluated to assess their durability after exposure to heat aging at $100^{\circ} \mathrm{C}$ and $125^{\circ} \mathrm{C}$ and to chemical compatibility with six heat transfer fluids at room temperature and at $70^{\circ} \mathrm{C}$.

The results of the laboratory tests are presented and a draft standard to screen plastic containment materials is proposed.

12. KEY WORDS (Six to twelve entries; alphabetical order: capitalize only proper names; and separate key words by semicolons) durability; plastic containnent materials; solar energy systems; standards

13. AVAILABILITY

UX Unlimited

$\square$ For Official Distribution. Do Not Release to NTIS

Order From Superintendent of Documents, U.S. Government Printing Office, Washington, D.C. 20402.

XX Order From National Technical Information Service (NTIS), Springfield, VA. 2216I
14. NO. OF PRINTED PAGES

15. Price 

